\title{
TECTONICS OF ROCK LOOSENING: GEOLOGICAL DATA AND PHYSICS OF THE PROCESS
}

\author{
M.G. Leonov $\oplus^{1 \bowtie}$, G.G. Kocharyan $\oplus^{2}$, A.F. Revuzhenko $\oplus^{3}$, S.V. Lavrikov $\oplus^{3}$
}

${ }^{1}$ Geological Institute, Russian Academy of Sciences, 7 Pyzhevsky Ln, Moscow 119017, Russia

${ }^{2}$ Institute of Geosphere Dynamics, Russian Academy of Sciences, 38/1 Leninsky Ave, Moscow 119334, Russia

${ }^{3}$ Institute of Mining, Siberian Branch of the Russian Academy of Sciences, 54 Krasny Ave, Novosibirsk 119334, Russia

ABSTRACT. Block-granular geological objects and rock volumetric mobility indicators are described. The mechanisms of structural and material reworking of rocks are considered in relation to the formation of a discrete tectonic structure of rocks and changes in the shapes of the geological bodies, which take place without rupturing the rock surfaces bounding these bodies and provide for the volumetric tectonic flow of solid rocks. Based on the study of natural objects and their comparison with the theoretical and experimental data on solid mechanics and geomechanics, it is suggested that one of the triggers for the volumetric disintegration of rock masses is rock fatigue damage (a fundamental phenomenon of solid-state physics). The disintegrated rocks behave according to the laws of mechanics of granular materials and mesomechanics. This study is of both theoretical and pragmatic importance as it contributes to the understanding of the regional geological features and provides new knowledge on the formation of crystalline protrusions known among the main hydrocarbon reservoirs within the basements of various geologic structures.

KEYWORDS: rock; granulated material; rock failure; disintegration; destruction; deformation; protrusion; tectonic flow; rock fatigue; tectonics of rock loosening

FUNDING: The study was carried out under the state assignment of the Geological Institute RAS (Description of deformation types and mechanisms) and financially supported by the Russian Science Foundation (project 16-17-10059Description of the post-magmatic structure of granites, general problems of mechanics and physics of structural disintegration of rocks).

\section{RESEARCH ARTICLE}

Correspondence: Mikhail G. Leonov, mgleonov@yandex.ru
Received: December 16, 2019

Revised: February 17, 2020

Accepted: March 11, 2020

FOR CITATION: Leonov M.G., Kocharyan G.G., Revuzhenko A.F., Lavrikov S.V., 2020. Tectonics of rock loosening: geological data and physics of the process. Geodynamics \& Tectonophysics 11 (3), 491-521. doi:10.5800/GT-2020-11-3-0488 


\title{
ТЕКТОНИКА РАЗРЫХЛЕНИЯ: ГЕОЛОГИЧЕСКИЕ ДАННЫЕ И ФИЗИКА ПРОЦЕССА
}

\author{
М.Г. Леонов ${ }^{1}$, Г.Г. Кочарян ${ }^{2}$, А.Ф. Ревуженко ${ }^{3}$, С.В. Лавриков ${ }^{3}$
}

\author{
${ }^{1}$ Геологический институт РАН, 119017, Москва, Пыжевский пер., 7, Россия \\ ${ }^{2}$ Институт динамики геосфер РАН, 119334, Москва, Ленинский пр-т, 38, корп. 1, Россия \\ ${ }^{3}$ Институт горного дела СО РАН, 630091, Новосибирск, Красный пр-т, 54, Россия
}

\begin{abstract}
АННОТАЦИЯ. В статье приведено описание геологических объектов, имеющих блоково-гранулярную инфраструктуру и признаки объемной подвижности породных масс. Указаны механизмы структурно-вещественной переработки, обеспечивающие возникновение дискретной тектонической структуры горных пород, изменение формы геологических тел без разрыва сплошности ограничивающей эти тела поверхности, а также делающие возможным объемное тектоническое течение пород в твердом состоянии. На основе изучения природных объектов и их сопоставления с теоретическими и экспериментальными данными механики твердого тела и геомеханики высказано предположение, что одним из факторов (триггеров), инициирующих процесс объемной дезинтеграции породных массивов, является усталостное разрушение горных пород - одно из фундаментальных явлений физики твердого тела, а поведение дезинтегрированных горных пород подчиняется законам механики гранулированных сред и мезомеханики. Исследование, кроме теоретического, имеет и прагматическое значение, так как позволяет глубже понять особенности региональной геологии, а также процесс формирования кристаллических тел протыкания (протрузий), являющихся одним из основных вместилищ углеводородов в пределах фундамента различных геоструктур.
\end{abstract}

КЛЮЧЕВЫЕ СЛОВА: горная порода; гранулированная среда; деструкция; деформация; протрузия; тектоническое течение; усталость; тектоника разрыхления

ФИНАНСИРОВАНИЕ: Работа выполнена по теме Госзадания ФГБУН ГИН РАН (описание типов и механизмов деформации) при финансовой поддержке Российского научного фонда (проект № 16-17-10059 - описание постмагматической структуры гранитов, общие вопросы механики и физики процесса структурной дезинтеграции горных пород).

\section{1. ВВЕДЕНИЕ}

Изучение механизмов 3D-деформации и тектонической подвижности горных пород необходимо для познания природы процессов структурообразования. Особенно важен синтез данных геологических исследований и экспериментальных и теоретических данных физики твердого тела и геомеханики. Совмещение этих двух подходов увеличивает вероятность правильного истолкования механизмов и физической сущности структурно-геологических процессов, происходящих в земной коре. Значительные успехи достигнуты в изучении геомеханики разломов [Adushkin et al., 2016; Kocharyan, 2016; Kuzmin, 2014; Mukhamediev, 2016; Rodionov et al., 1986; Ruzhich,1997; Sadovsky et al., 1988; Seminsky, 2003; Sherman, 2014; Sherman et al., 1991, 1992, 1994], которые охватывают весь спектр хрупкой деформации от внутрикристаллических микротрещин до трансконтинентальных разломных зон, однако при этом и в геологии, и в геомеханике меньше внимания уделяется 3D-деформации геологических тел, не связанной непосредственно с разломами или с зонами их влияния.

С целью хотя бы частичного восполнения этого пробела нами описаны объекты, не имеющие разломных ограничений и обладающие автономной инфраструктурой. Тектонические срывы, возникающие на границах тел из-за дисгармонии инфраструктуры и структуры обрамления, не препятствуют такому подходу. В статье сделана попытка провести корреляцию структурногеологических данных и экспериментально-теоретических положений физики твердого тела и геомеханики. Предметом статьи являются: (1) описание геологических объектов, для которых характерны гранулярноблочная инфраструктура (исходная или возникшая в процессе тектонической эволюции) и признаки объемного течения; (2) непротиворечивое толкование физики процесса деформации блоково-гранулированных породных сред; (3) оценка роли тектоники разрыхления в формировании структуры консолидированного слоя земной коры.

\section{2. СТРУКТУРНО-ГЕОЛОГИЧЕСКИЕ ДАННЫЕ}

Известно [Azhgirey, 1966; King, 1967; Leonov, 2008; Leonov et al., 2018; Lukyanov, 1991; Reiner, 1947; Sherman, Gorbunova, 2018; Carey, 1954], что горным породам и геологическим телам во многих случаях свойственны признаки 3D-подвижности (текучести) или реидной ${ }^{1}$

${ }^{1}$ Реидность (от греч. «рєоৎ» - течение) - способность горных пород к течению в твердом состоянии. Понятие охватывает совокупность вязкого, пластического, катакластического и прочих видов течения. Введено [King, 1967; Сarey, 1954] в силу того, что в природных объектах одномоментно могут проявляться разные механизмы необратимой деформации. Понятие «реидное течение» в механике твердых тел эквивалентно понятию «тектоническое течение» в геологии. 
деформации. Выявлены механизмы структурной переработки пород, обеспечивающие 3D-реидную деформацию и внутреннюю подвижность геологических тел без разрыва сплошности их граничной поверхности [Leonov, 2008; Leonov et al., 2018] (рис. 1). Это пластическая деформация, меланжирование, хрупкая макросколовая (блоковая) и микросколовая (кливажная) деформация, катаклаз, динамическая рекристаллизация. Каждый из этих механизмов или некая их совокупность приводят к возникновению дискретной блочно-гранулярной инфраструктуры пород. При этом величина гранул и блоков может варьировать от частиц наноразмерности [Sobolev et al., 2016] до горных массивов и иметь фрактальный характер [Gol'din, 2002, 2005; Kocharyan, 2016; Kocharyan, Spivak, 2003; Ruzhich, 1997; Sadovsky, 1989; Sadovsky et al., 1988] (рис. 2, 3, 4, 5).

\section{1. Деформация осадочных и метаосадочных пород}

В пределах Карельского массива (Балтийский щит) выделяется архейский фундамент и палеопротерозойский проточехол. Отложения проточехла, в том числе выполняющие Онежскую и Сегозерскую мульды (рис. 6), испытали структурно-вещественные преобразования, связанные с внутрипластовым течением пород [Kolodyazhny, 2006; Kolodyazhny et al., 2000; Kopeliovich, Simanovich, 1963; Leonov, 2008].

На юго-западном борту Сегозерской мульды, на берегу оз. Сегозеро, обнажен фрагмент разреза сегозерской свиты ятулия, представленный переслаиванием андезибазальтов, косослоистых пестроцветных кварцитопесчаников и белых кварцитов (рис. 6, пункт 1 на врезке). Породы залегают со слабым наклоном (10-15) к центру мульды и разбиты серией вертикальных, в основном зияющих трещин отрыва, реже - трещин скола. Трещины возникли после образования всей колонны осадков и их литификации и делят пласты на ортогональные блоки. Трещины бывают «сквозные», рассекающие всю колонну отложений, но многие трещины развиты только в слое белых кварцитопесчаников и не проникают в подстилающие и перекрывающие пласты. В этих пластах сеть трещин более частая, а размер выкалываемых блоков меньше, чем в ниже- и вышележащих пластах диабазов и красноцветных кварцитопесчаников. (a)

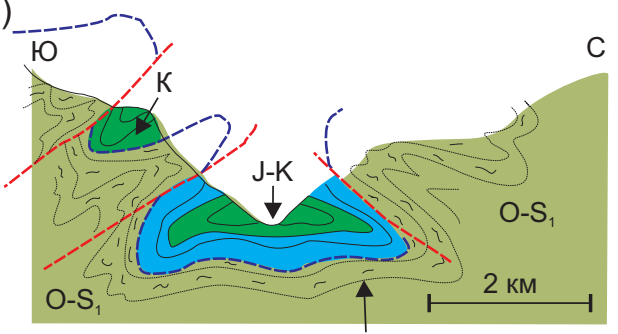

Зеленые сланцы Ягнобского комплекса

(2)

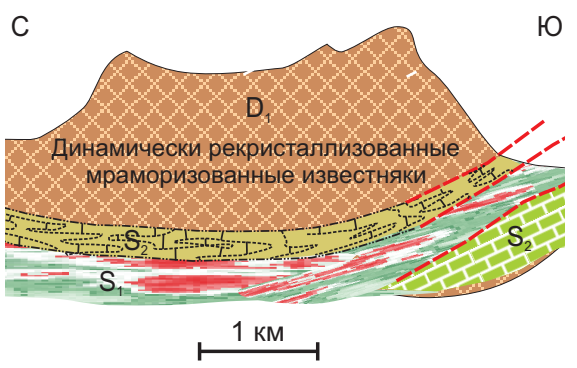

(б)

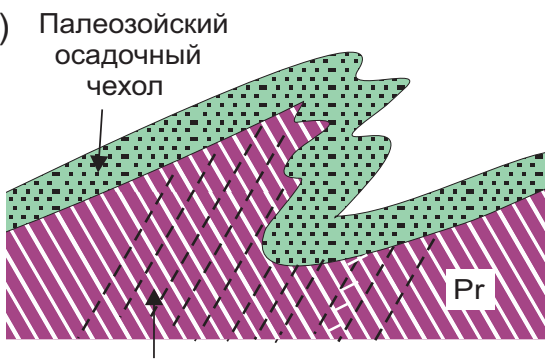

Породы докембрийского фундамента
(8)

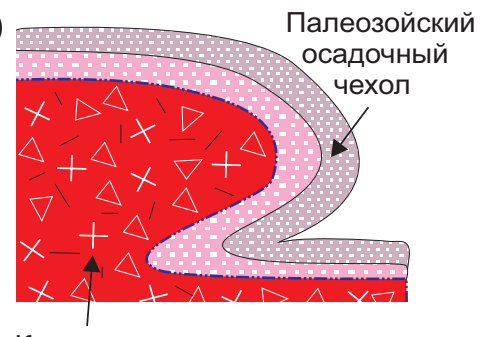

Катаклазированные граниты докембрийского фундамента (d)

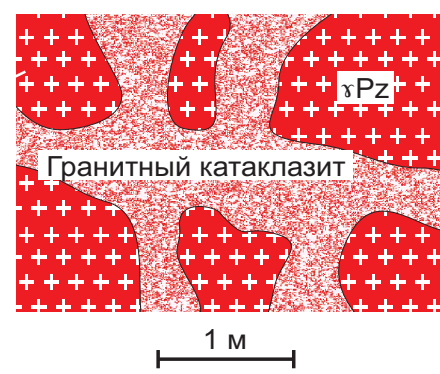

(e) $\mathrm{c}$

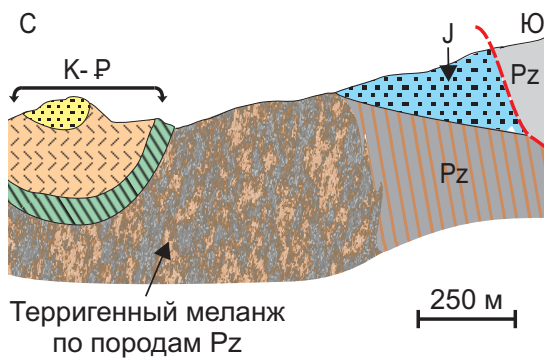

Рис. 1. Механизмы структурно-вещественной переработки, обеспечивающие 3D-подвижность горных пород и деформацию поверхности фундамента без разрыва оплошности.

(a) - пластическая деформация (Раватская впадина, Южный Тянь-Шань); (б) - хрупкая микродеформация (кливажная) (Армориканский массив) [Bradschaw et al., 1967]; (в) - разломно-блоковая мезо- и макродеформация (по [Beroush, 1991]); (2) динамическая рекристаллизация (Фанские горы, Южный Тянь-Шань); (d) - брекчирование и катаклаз (Дзирульский массив); (e) - меланжирование (Зеравшанская зона, Южный Тянь-Шань).

Fig. 1. Structural and material reworking mechanisms that provide 3D rock mobility and deformation of the basement surface without rupture of solidity.

(a) - plastic deformation (Rawat Trench, South Tian Shan); (б) - fragile cleavage microdeformation (Armorica massif) [Bradschaw et al., 1967]; (8) - fracture-block mezo- and macrodeformation (by [Beroush, 1991]) (2) - dynamic recrystalization (Fan Mountains, South Tian Shan); $(\partial)$ - breccias and cataclasit formation (Dzirula massif, Caucasus); $(e)$ - mélange formation (Zeravshan zone, South Tian Shan). 


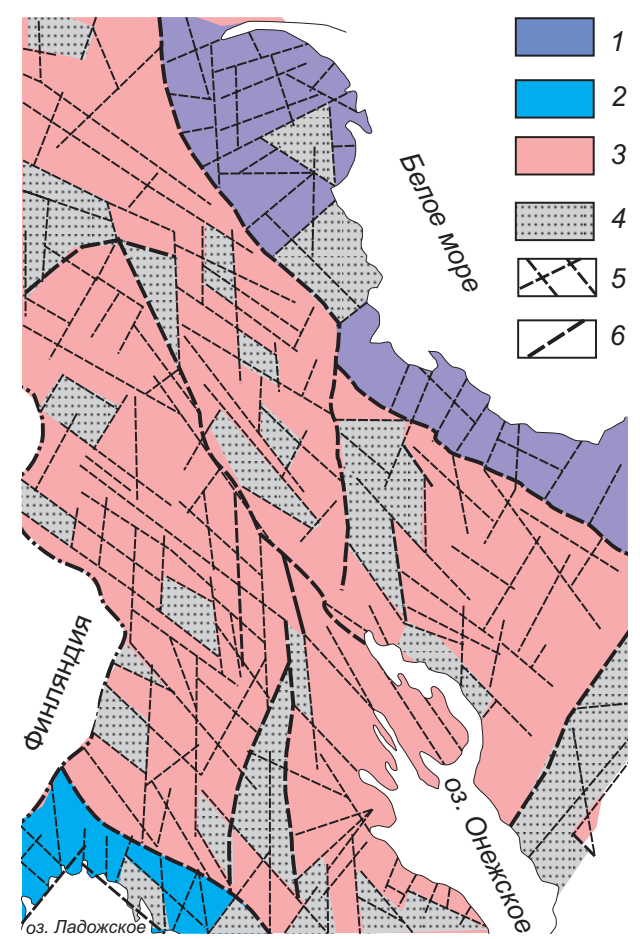

Рис. 2. Разломно-блоковая дезинтеграция мегауровня (Карельский массив) (по [Lukashov, 1974]).

1-3 - геологические провинции: 1 - свекофенниды, 2 - беломориды, 3 - Карельский массив; 4 - опущенные блоки фундамента; 5 - линеаменты и разломы; 6 - границы провинций и главные структурные линии.

Fig. 2. Fracture-block disintegration of the Karelian massifs (by [Lukashov 1974]).

1-3 - geological provinces: 1 - Svekofennides, 2 - Belomorides, 3 Karelian massif; 4 - lowered basement blocks; 5 - lineaments and faults; 6 - boundaries of provinces and main structural lines.
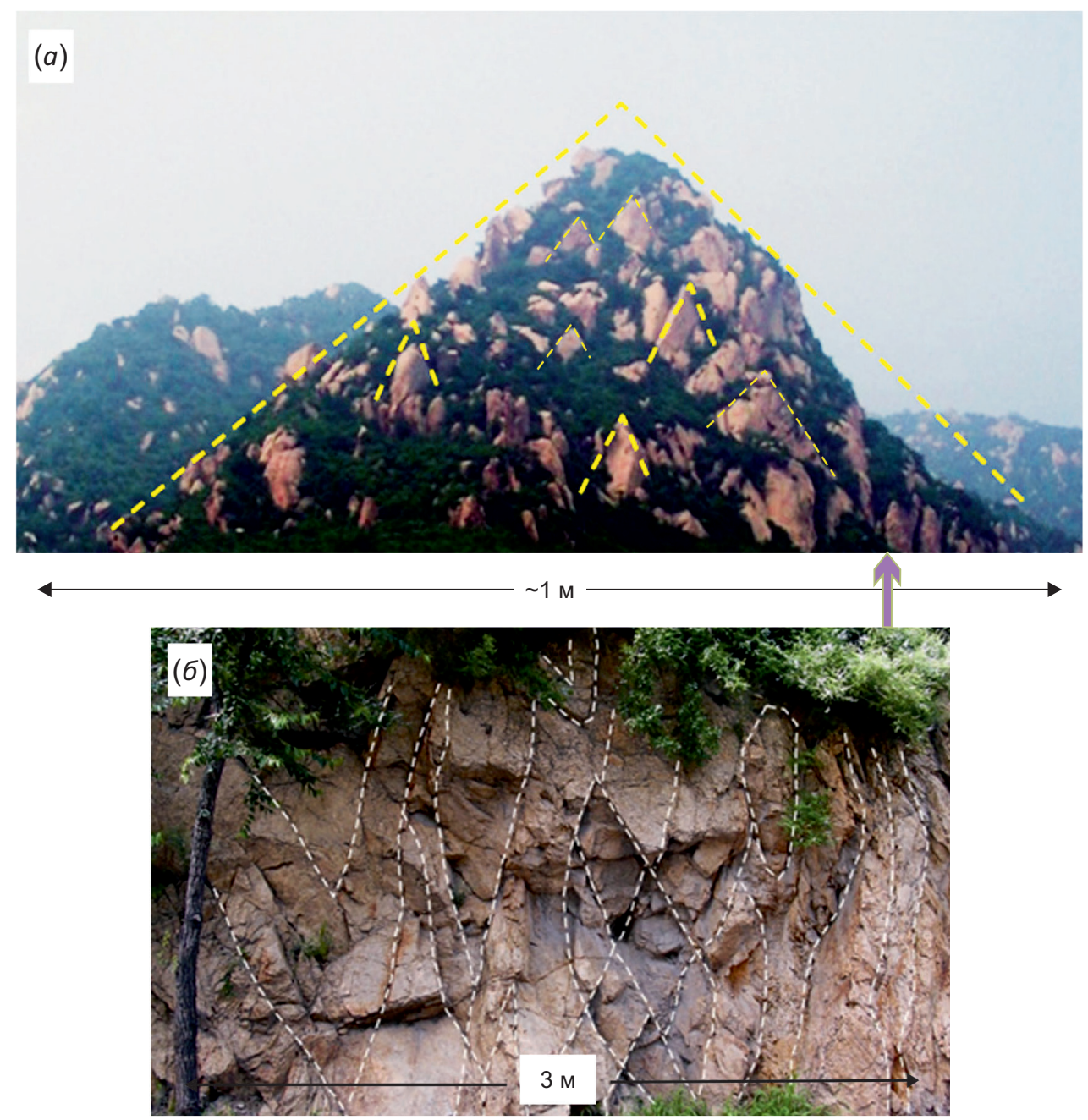

Рис. 3. Фрактальная делимость в гранитах $\left(\mathrm{J}_{3}-\mathrm{K}_{1}\right)$ Яньшаньской гряды (Китай). (a) - мега- и макроуровень, (б) - мезоуровень. Fig. 3. Fractal divisibility in the Yanshan Ridge (China) granites $\left(\mathrm{J}_{3}-\mathrm{K}_{1}\right)$. (a) - mega- and macroscales, (б) - mesoscale. 


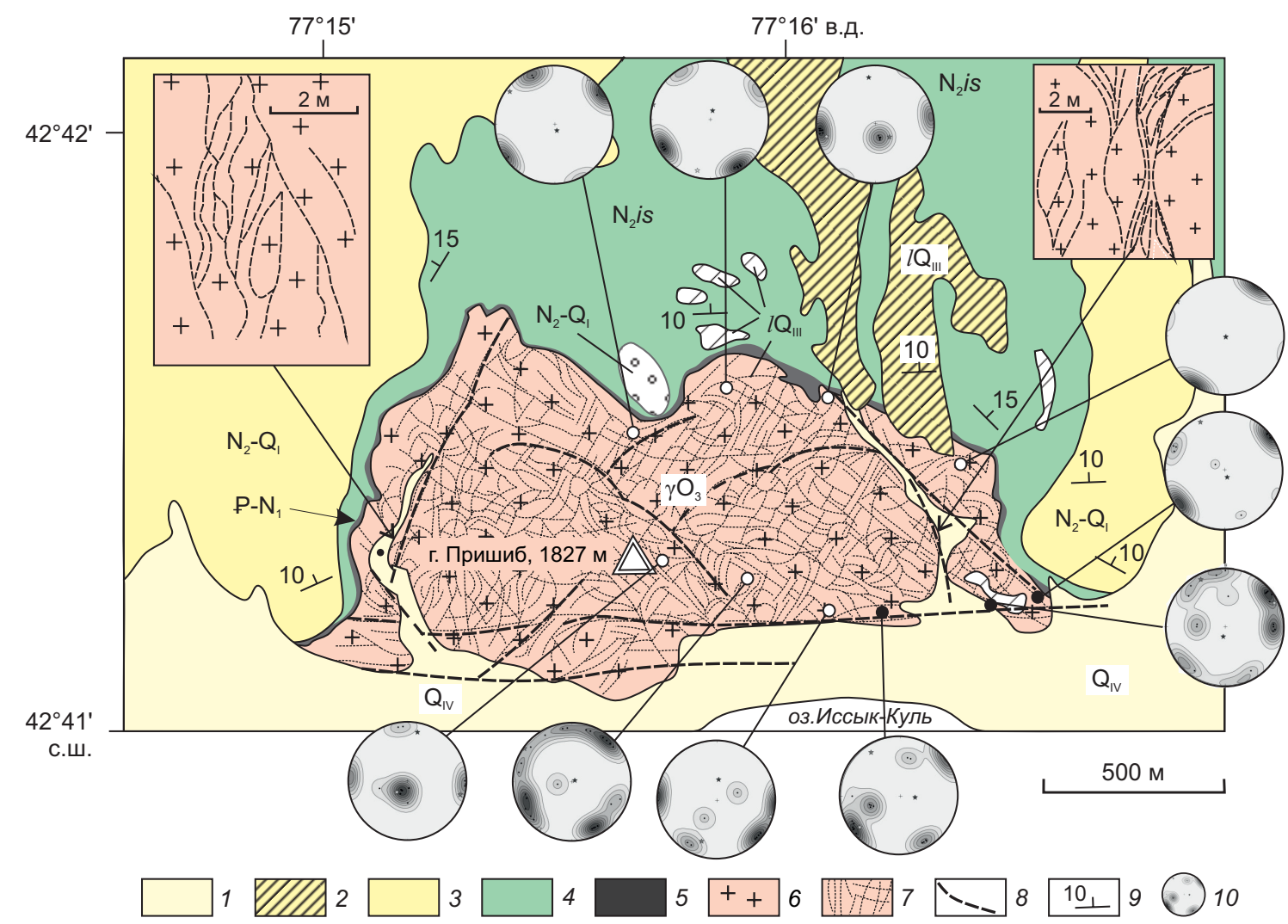

Рис. 4. Инфраструктура мезоуровня в гранитах массива Пришиб (Тянь-Шань).

Стереограммы отражают локальные поля напряжений в отдельных породных фрагментах фундамента. 1 - коллювий и пролювий; 2 - лессы (верхний плейстоцен); 3-5 - горизонты и свиты палеогена - неогена; 6 - граниты (0); 7 - трещиноватость в гранитах; 8 -разломы; 9 - элементы залегания; 10 - стереограммы плотностей полюсов трещин в гранитах (нижняя полусфера).

Fig. 4. Mesoscale infrastructure in granites of the Prishib massif (Tian Shan).

Stereograms reflect local stress fields in separate rock fragments of the basement. 1 - colluvium and proluvium; 2 - loess (upper Pleistocene); 3-5 - Paleogene-Neogene horizons and suites; 6 - granites (0); 7 - cracks systems in granites; 8 - faults; 9 - layering elements; 10 - stereograms of the cracks poles density in granites (lower hemisphere).
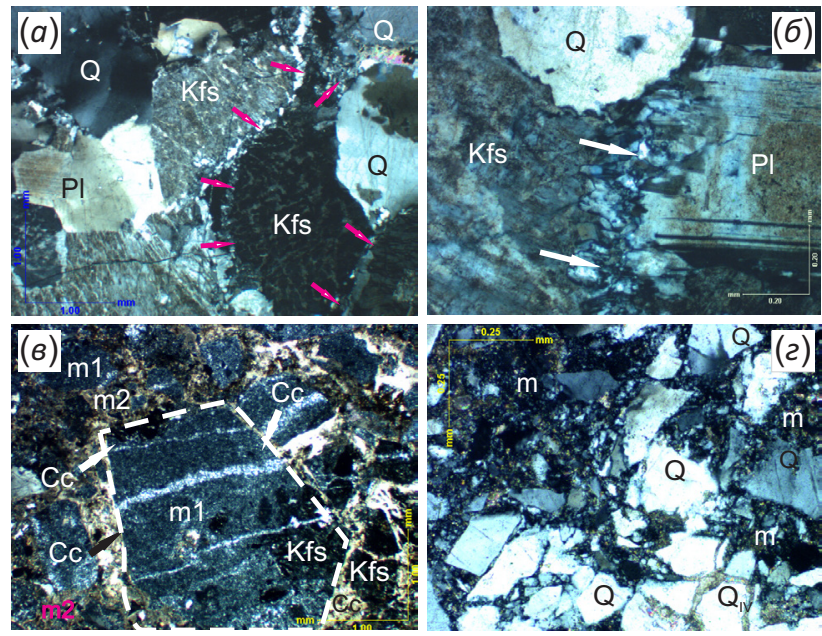

$(\partial)$

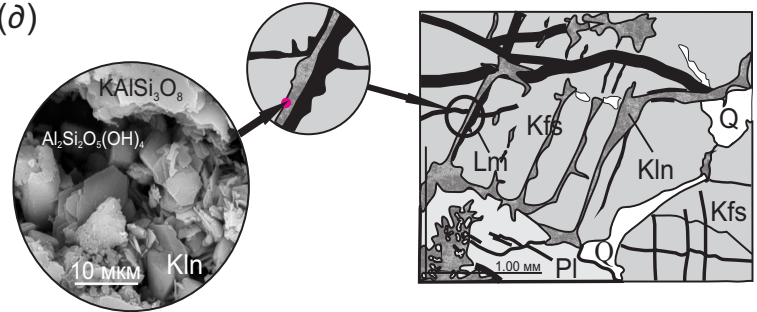

Рис. 5. Деформация микроуровня и синтектоническая минерализация гранитов массива Танын (Гобийский Алтай) (фото и интерпретация Е.В. Лаврушиной [Leonov et al., 2018]).

(a), (б) - кварц-полевошпатовые агрегаты (показаны стрелками) - продукт динамической рекристаллизации; (в) - микробрекчия с каолинит-кальцитовым матриксом; (2) - микробрекчия с кластами кварца и полевого шпата в каолиниткальцитовом матриксе; $(\partial)$ - развитие каолинита по трещинам спайности ортоклаза. Аббревиатуры: Сс - кальцит, Kfs - калиевый полевой шпат, Kln - каолинит, Pl - плагиоклаз, Q - кварц, $\mathrm{m} 1$ - микробрекчия первой генерации, $\mathrm{m} 2$ - микробрекчия второй генерации.

Fig. 5. Microscale deformation and sintectonic mineralization of Tanyn (Gobi Altai) granites (photo and interpretation by E.V. Lavrushina [Leonov et al., 2018]).

(a), (б) - quartz-feld-spar aggregates (shown by arrows) - a product of dynamic recrystallization; $(\theta)$ - microbreccia with kaolinitecalcite matrix; (2) - microbreccia with quartz and feldspar klasts in kaolinite-calcitic matrix; $(\partial)$ - kaolinite developed in cleavage cracks within orthoclase crystals. Abbreviations: Cc - calcite, Kfs potassium feldspar, Kln - kaolinite, Pl - plagioclase, Q - quartz, $\mathrm{m} 1$ - microbreccia of the first generation, $\mathrm{m} 2$ - microbreccia of the second generation. 
Субширотные трещины отрыва ассоциируют со стилолитовыми швами нескольких генераций (рис. 7), субмеридиональные трещины не сопровождаются стилолитами. Плоскости стилолитовых швов перпендикулярны к поверхностям напластования при субмеридиональной ориентировке зубцов, размах которых составляет до 10-15 см. Внутри блоков, ограниченных трещинами, расположены замкнутые или разорванные кольцеобразные образования, сформированные выделениями окислов железа (гематит?). Ожелезненные микрообъемы смещены относительно друг друга по множеству вертикальных микрокливажных плоскостей, тонкой сетью пронизывающих пласт белых кварцитопесчаников, но не проникающих за его пределы.

Комплекс структур - парагенез субширотных трещин отрыва и субвертикальных стилолитовых швов нескольких генераций, кливаж сланцеватости, микроструктурные изменения, характер перераспределения окислов железа - указывает на внутрислоевое тектоническое течение пород при периодической смене обстановок укорочения и удлинения. Течение осуществляется за счет дифференцированного зернограничного скольжения, индикатором которого является смещение синкинематических выделений окислов железа и зерен кварца, отороченных пленками окислов железа. Перемещение вещества происходит в плоскости напластования, но за счет возникновения вертикальных слайдов - множества параллельных микрообъемов, на границах и внутри которых происходило относительное смещение элементарных составляющих породы (микрокливаж сланцеватости). Пластическая деформация подчеркивается и цепочкой линзовидных выделений кварца.

Структуры субслойного течения развиты также в породах петрозаводской и шокшинской свит [Leonov, 2008]. В петрозаводской свите (см. рис. 6, пункт 2 на врезке)

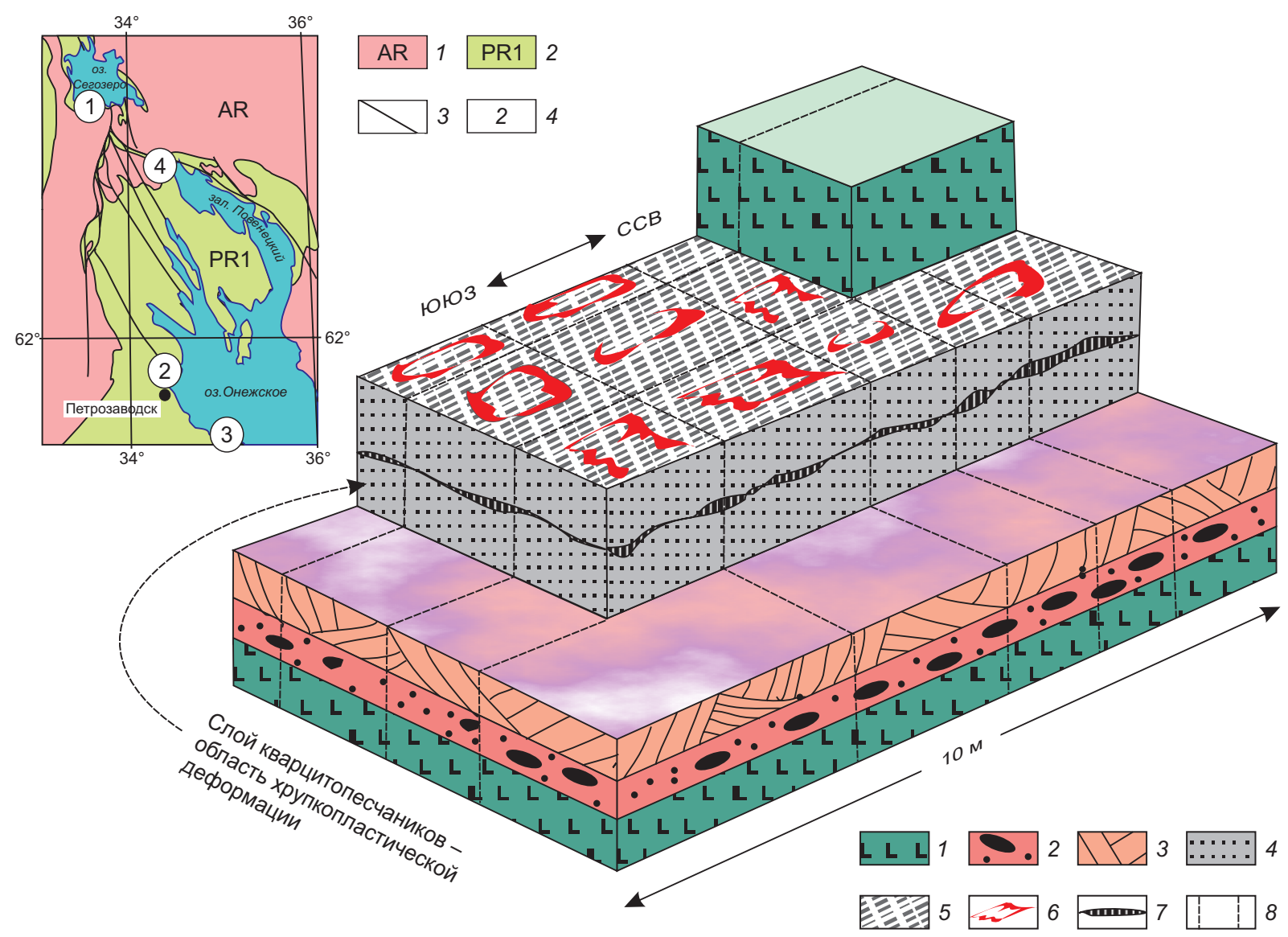

Рис. 6. Фрагмент разреза сегозерской свиты (юго-западный берег оз. Сегозеро) (блок-диаграмма). На карте-врезке - схема расположения изученных объектов в пределах Сегозерской и Онежской мульд (Карельский массив).

Условные обозначения к карте-врезке: 1 - архейский фундамент; 2 - палеопротерозойский проточехол; 3 - основные разломы; 4 - объекты, описание которых приведено в статье. Условные обозначения к блок-диаграмме: 1 - диабазы; 2 - конгломераты; 3 - пестроцветные кварцитопесчаники, косослоистые; 4 - белые кварциты; 5 - кливаж сланцеватости в кварцитах; 6 - структурно обусловленные выделения гематита; 7 - линзовидные выделения кварца; 8 - трещины скалывания и отрыва.

Fig. 6. Segozero suite fragment (southwestern shore of Lake Segozero).

1 - diabases; 2 - conglomerates; 3 - multicolored quartzite-sandstones, cross bedded; 4 - white quartzites; 5 - slaty cleavage in quartzites; 6 - structurally conditioned hematite segregations; 7 - lens-shaped selections of quartz; 8 - shear and tensile cracks.

Schematic map showing locations of the studied objects within the Segozero and Onega depressions (Karelian massif). 1 - Archaic basement; 2 - Paleoproterozoic protocover; 3 - major faults; 4 - objects described in the texts. 

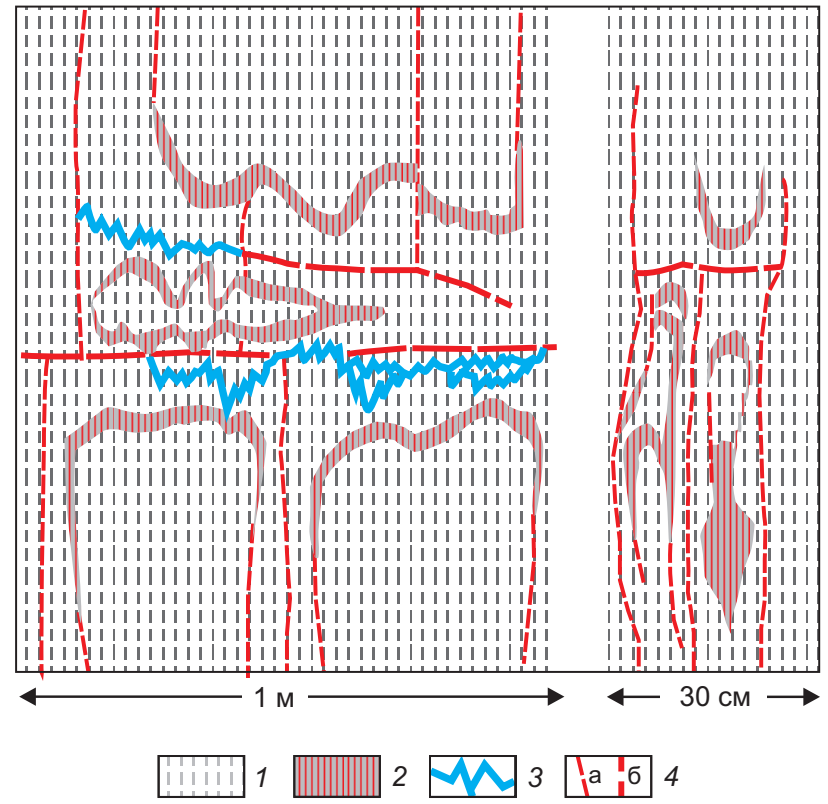

Рис. 7. Инфраструктура кварцитов сегозерской свиты (югозападный берег оз. Сегозеро) (план).

1 - кварциты с вертикальным кливажом сланцеватости; 2 структурно обусловленные выделения гематита; 3 - стилолитовые швы; 4 - трещины: а - скола, б - отрыва.

Fig. 7. Infrastructure of quartzites of the Segozero suite (southwestern shore of Lake Segozero) (plan).

1 - quartzites with vertical slaty cleavage; 2 - structurally conditioned hematite segregations; 3 - stylolite seams; 4 - cracks: a - shear cracks, $\sigma$ - breakaway crack.

объемная подвижность обусловлена возникновением системы поверхностей хрупкопластического скалывания, межслоевых зон проскальзывания и подвижных ромбоэдровидных доменов (рис. 8).

В шокшинской свите (см. рис. 6, пункт 3 на врезке; рис. 9) деформации макромасштаба представлены секущими взбросами и надвигами, межпластовыми срывами, субвертикальными сдвигами, пронизаны притертыми трещинами с зеркалами скольжения, ориентированными как в направлении слоистости, так и под углом к ней. Эти структуры указывают на послойные перемещения, а также на секущие надвиговые и взбросо-сдвиговые смещения, которые фиксируют крупноблоковую объемную деформацию. В породах наблюдаются эпигенетические изменения (динамический катагенез, метагенез, динамометаморфизм), свидетельствующие о внутренней пластичности и объемной подвижности пород в масштабе отдельных слоев, пачек и горизонтов. Внутрипластовое скольжение осуществляется на уровне слойков, зерен и их частей, а также кристаллической решетки минералов [Kopeliovich, Simanovich, 1963]. Благодаря синтектоническому выделению окислов железа, образуется структурно-вещественная полосчатость и возникают внутрислойные псевдоскладчатые структуры. Их формирование связано с дифференцированным перемещением зерен и кристаллов в плоскости напластования (рис. 9). Внутрислоевое и межслоевое сдвиговое течение широко распространены в метаосадочных толщах Карельского массива [Kolodyazhny, 2006; Miller, 1997].

Моренный комплекс Калязинского Поволжья (Восточно-Европейская платформа). Одним из объектов, отражающих объемную деформацию рыхлых отложений, являются гляциодислокации моренного комплекса Калининского позднеплейстоценового ледникового покрова (рис. 10) [Lavrushin, Chistyakova, 2001], большую роль в изучении которых сыграл О.Г. Эпштейн [Leonov, 2008]. Гляциокомплекс сложен четвертичными глинисто-глыбовыми моренами и флювиогляциальными отложениями, которые прорваны протрузией мел-палеогеновых светло-розовых и белых песков и юрских черных глин. Для песчаных отложений обоих комплексов характерны отсутствие выраженной осадочной слоистости и зернистая (гранулярная) структура.

В отложениях гляциального комплекса фиксируются лежачие изоклинальные складки, в строении которых участвуют моренные глины (рис. 10,11).

Пласты в крыльях складок растащены и превращены в серию кулисно расположенных, «вложенных» одна в другую сжатых лежачих антиклиналей с субпараллельными крыльями. Замки складок острые, осложненные мелкими дисгармоничными складочками и гофрировкой более высоких порядков и растащенные на отдельные фрагменты с образованием псевдокливажной и псевдосланцеватой структуры. В результате пластического перераспределения материала - оттока из крыльев и нагнетания в замки складок и пластического растекания («рассеивания») их ядерных частей - возникает структурная дисгармония. Происходит

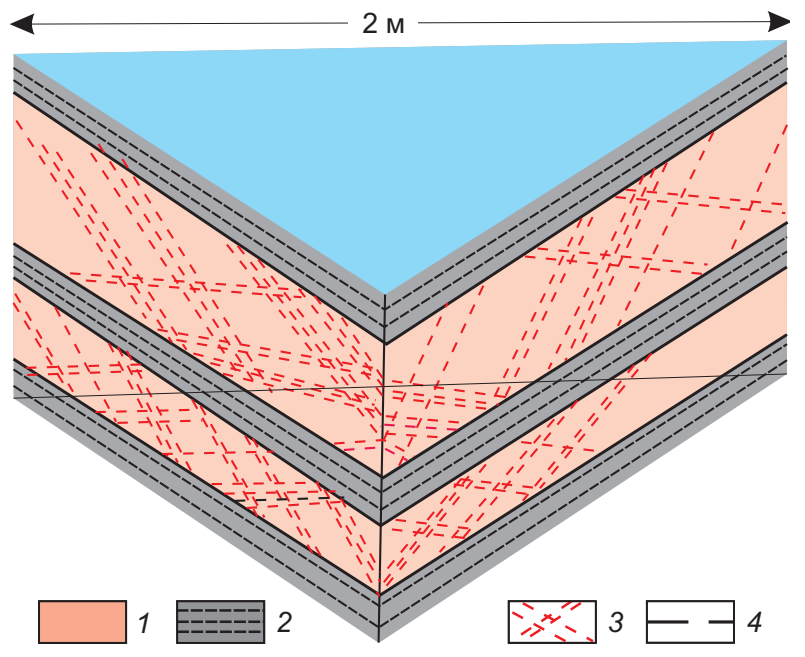

Рис. 8. Кливажная деформация в сланцево-песчаных породах петрозаводской свиты. Зарисовка обнажения (пос. Соломенное, Западное Прионежье).

1 - кварцитопесчаники; 2 - сланцы; 3 - трещины скола; 4 плоскости скольжения по границам слоев.

Fig. 8. Cleavage deformation in shale-sand rocks of the Petrosavodsk suite. Sketch of the outcrop (village Solomennoe, western shore of Lake Onega).

1 - quartzite-sandstones; 2 - schists; 3 - shear cracks; 4 - sliding planes over the layer boundaries. 
(a)
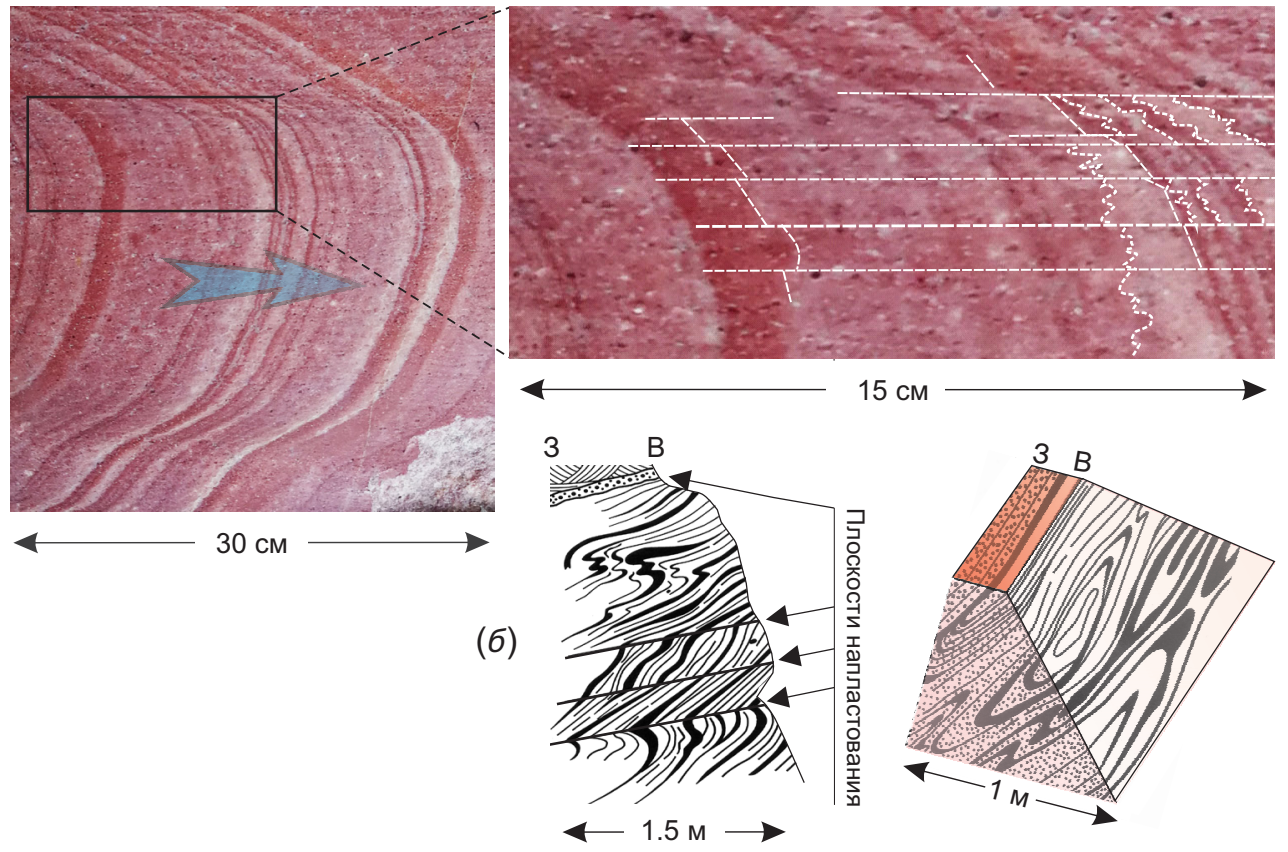

Рис. 9. Псевдоскладчатые структуры в красноцветных кварцитопесчаниках шокшинской свиты (западный берег Онежского озера); межзерновое скольжение элементарных объемов (гранул) зафиксировано структурно обусловленными выделениями гематита.

(a) - фотографии штуфа; прозрачная стрелка - направление потока; (б) - зарисовки обнажения: колчановидные псевдоскладки (черные полосы - выделения окислов железа).

Fig. 9. Pseudo-folding structures in red-colored quartzite-sandstones of the Shoksha suit (western shore of Lake Onega). Intergrain sliding of elementary volumes (granules) is marked by structurally conditioned hematite segregations.

(a) - piece of ore photos; transparent arrow - flow direction; (б) - sketches of the outcrop: sheath pseudo-folds (black stripes - iron oxides segregation).
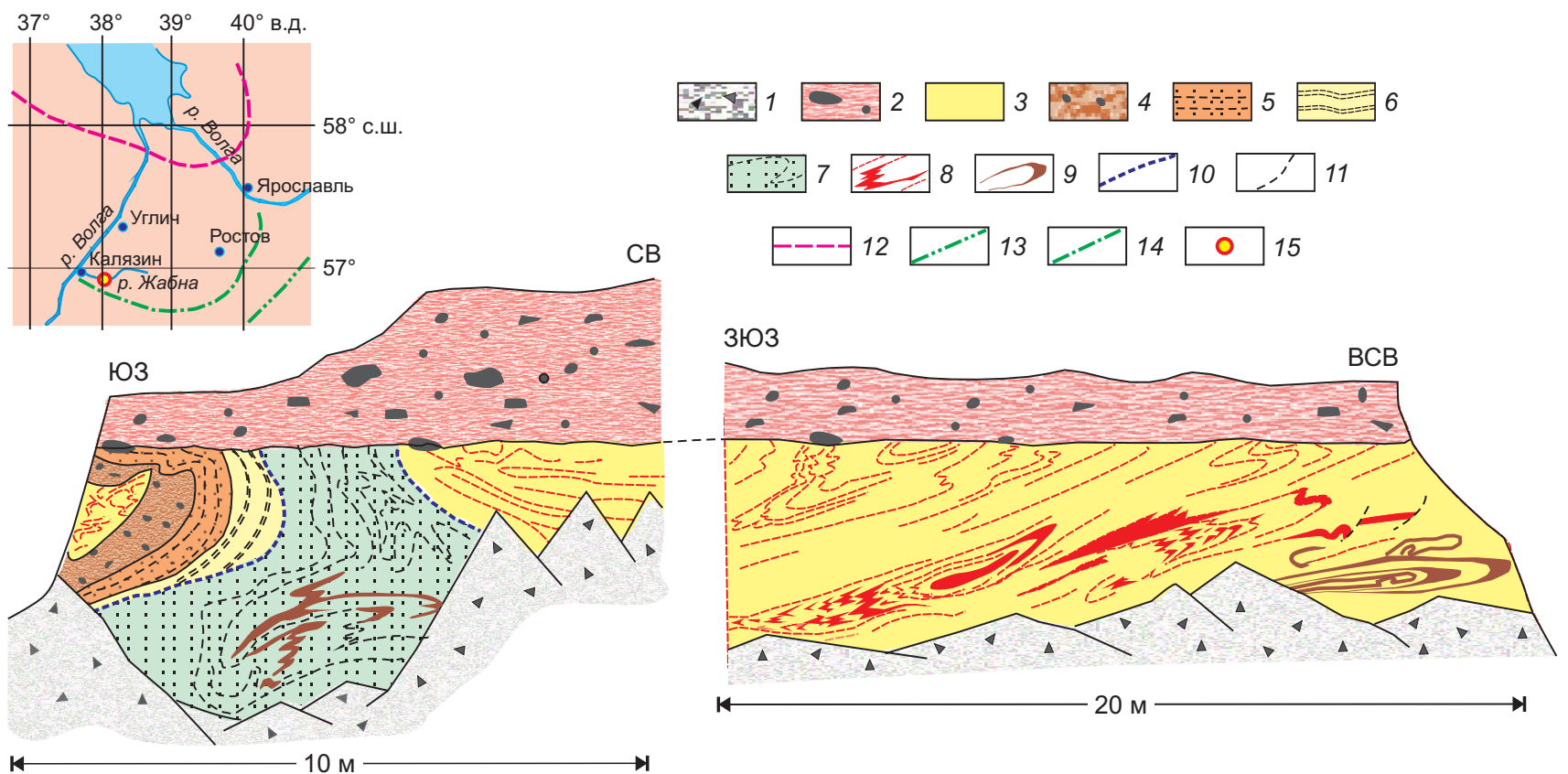

Рис. 10. Строение верхнечетвертичных гляциодислокаций (Калязинско-Ярославское Поволжье). Положение обнажения показано на карте-врезке (на основе [Lavrushin, Chistyakova, 2001]).

1 - осыпи; 2 - валунный микстит (верхняя морена); 3 - неяснослоистые ожелезненные пески с тонкими прослойками глины и алеврита; 4 - валунный микстит (нижняя морена); 5 - слоистые пестроцветные пески, алевриты и глины; 6 - тонкополосчатые пески и алевриты; 7 - белые и бело-розовые пески с пропластками глинистых песков и пакетов тонкослоистых буро-коричневых глин (протрузия отложений мелового возраста); 8 - объемы кварцевых песков, обогащенные окислами железа; 9 - включения красных моренных глин; 10 - граница протрузии меловых песков; 11 - разрывные нарушения в рыхлых песках; 
12 - лопастная линия Осташковского оледенения; 13 - линия максимальной стадии Калининского оледенения; 14 - лопастная линия Калининского оледенения на стадии деградации; 15 - местоположение изученного объекта.

Fig. 10. Upper Quaternary glaciodislocations (Kalyazin-Yaroslavl Volga region). The Borodulino glaciodislocation outcrop's position is shown in the inset map (based on [Lavrushin, Chistyakova, 2001]).

1 - talus; 2 - boulder mixtite (upper moraine); 3 - obscure-layered ferruginized sands with thin of clay and aleurite; 4 - boulder mixtite (lower moraine); 5 - layered multicolored sands, aleurites and clays; 6 - thin-striped sands and aleurites; 7 - white and white-pink sands with clay sands plates and thin-layered brown clays packets (Cretaceous sediment protrusion); 8 - volumes of quartz sands enriched with iron oxides; 9 - inclusion of red moraine clay; 10 - boundary of the Cretaceous sands protrusion; 11 - faults in loose sands; 12 - Ostashkov glaciation lobe line; 13 - line of the maximum stage of Kalinin glaciation; 14 - Kalinin glaciation lobe line at the stage of degradation; 15 - location of the object studied.

(a)

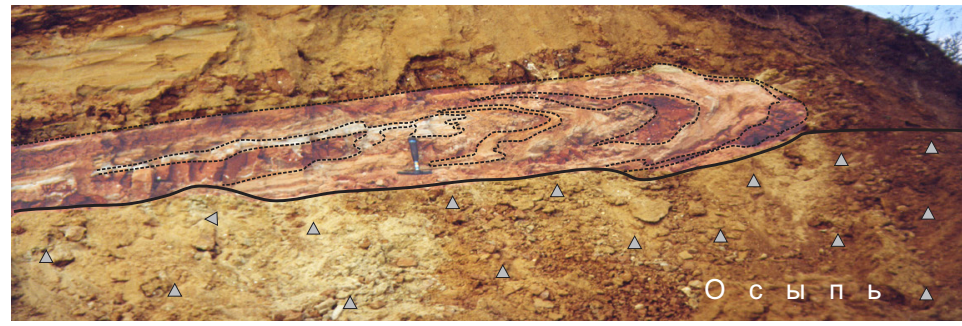

(б)

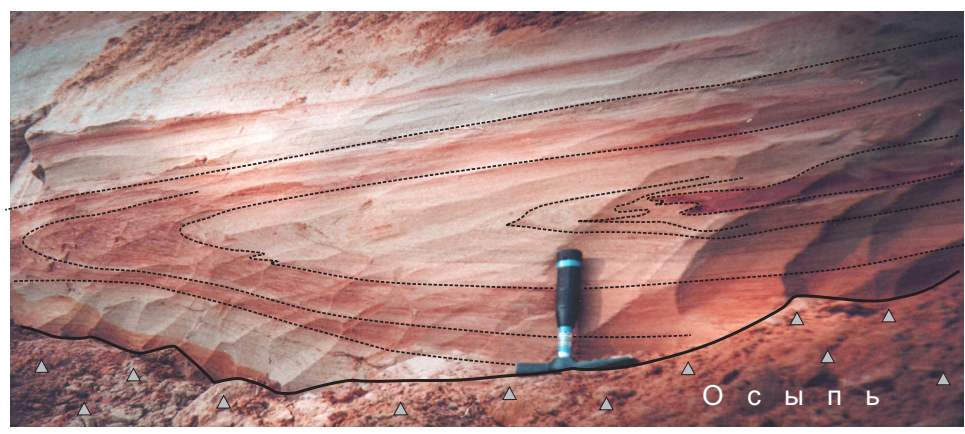

(в)

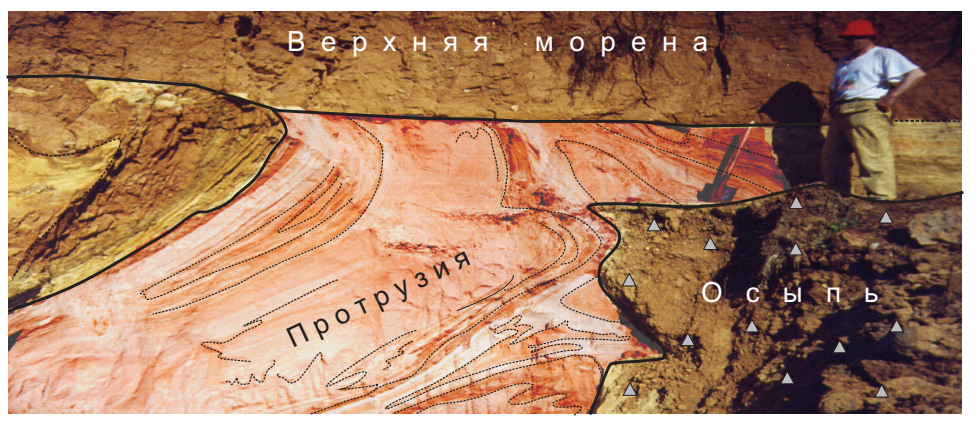

Рис. 11. Строение комплекса Бородулинских гляциодислокаций (фото). Описание в тексте.

Fig. 11. Structure of the Borodulino glaciodislocations (photos). Description in text.

расслоение пород и формирование вторичной дислокационной полосчатости, обусловленной тонким чередованием песков и красных глин. Дислокации затухают и возникают вновь по простиранию и по разрезу. Образуются зоны межслоевого проскальзывания, которые подчеркнуты выделениями окислов железа и тонким структурным переслаиванием песков и глин.

Ядра относительно крупных (протяженность до 25 м) пликативных структур, очерченных пластами моренных глин, сложены песками флювиогляциального комплекса. В песках фиксируется серия узких асимметричных лежачих складкоподобных структур с острыми замками - «псевдоскладок», а также колчановидные формы (см. рис. 10, 11, а, б, 12, а). Эти структуры по простиранию и по разрезу переходят в пески с субпараллельной расслоенностью или вообще без признаков полосчатости. Псевдоскладки осложнены пликативными формами более высоких порядков и пологими надвигами.

Псевдопликативные дислокации зафиксированы благодаря концентрации окислов железа, создающих структурно обусловленную полосчатость и маркирующих большинство структурных элементов в пределах моренного комплекса. Эти структуры в определенном смысле являются гомологами складок скалывания (кливажных складок). В глинистых разностях происходит пластическое перераспределение вещества sensu stricto, в песчаных - движение породной массы обусловлено 
(a)

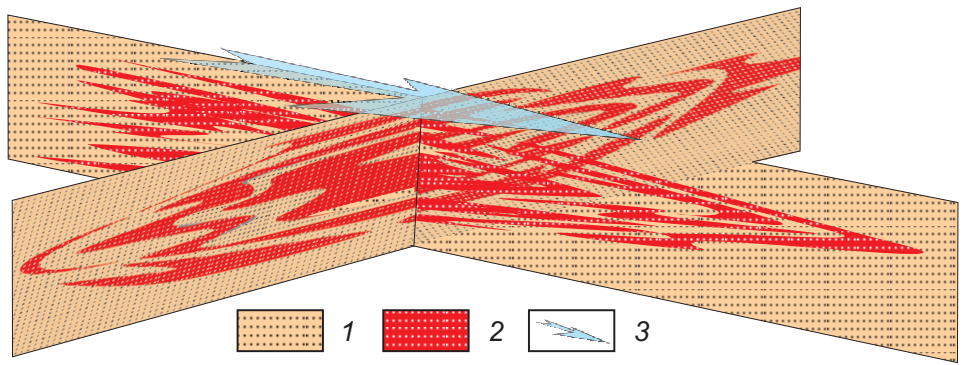

(б)
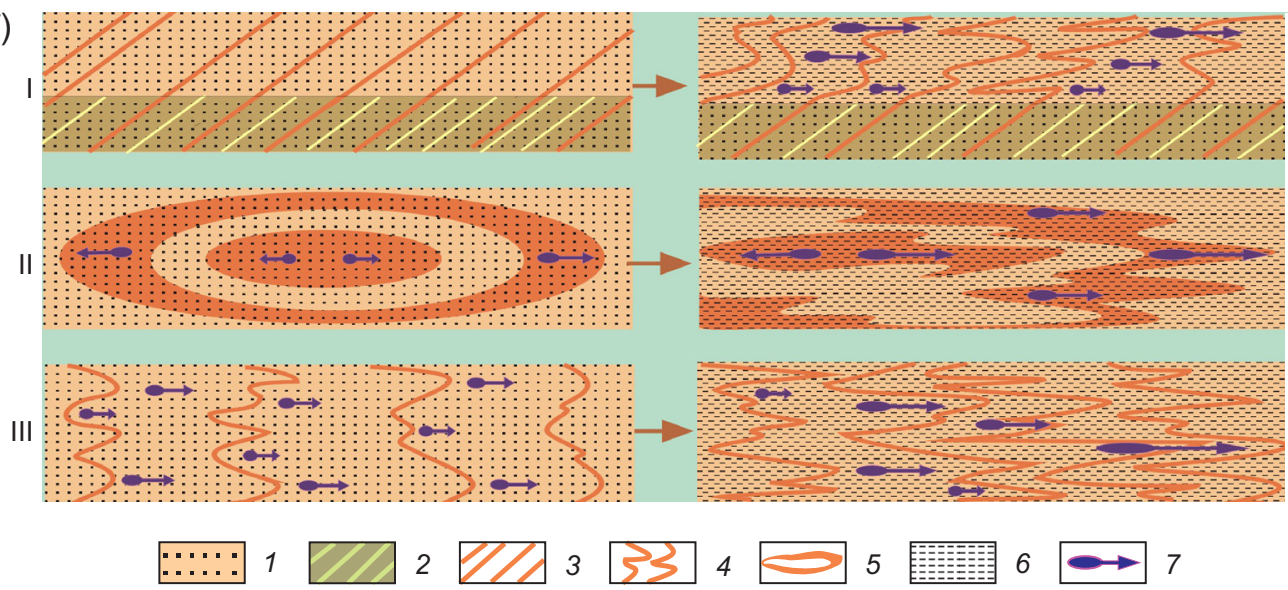

Рис. 12. Колчановидные псевдоскладки в песках гляциокомплекса Бородулино (a) и механизмы формирования структурнометаморфической полосчатости и 3D-течение зернистых сред (б).

Условные обозначения к фрагменту ( $a$ ): 1 - моно- и олигомиктовый песок; 2 - объемы песка, обогащенные окислами железа; 3 - направление течения зернового потока.

Условные обозначения к фрагменту (б): I - трансформация кливажных поверхностей; II - трансформация колец Лизеганга; III - синкинематическая дифференциация. Длина стрелок отражает относительную амплитуду перемещения гранул.

1 - кварцитопесчаники; 2 - косая слоистость; 3 - секущий кливаж; 4 - структурно обусловленные выделения окислов железа; 5 - кольца Лизеганга; 6 - поверхности межзернового скольжения и субслойный кливаж сланцеватости; 7 - амплитуда относительного смещения зерен и микрообъемов окислов железа.

Fig. 12. Sheath pseudo-folds within the sandy horizons of the Borodulino glaciocomplex $(a)$. Formation of structural-metamorphic foliation, and 3D granular flow (б).

Legend to (a): 1 - mono- and oligomyctic sand; 2 - sand volumes enriched iron oxides; 3 - grain flow direction. Legend to (б): I cleavage surface transformation; II - Liesegang rings transformation; III - differentiation simultaneous with tectonic flow. Arrow lengths reflect the relative amplitudes of granular movement. 1 - quartzite-sandstones; 2 - cross bedding; 3 - transverse cleavage; 4 structurally conditioned iron oxides segregations; 5 - Liesegang rings; 6 - surface of intergrain sliding and sublayered shale cleavage; 7 - amplitude of relative displacement of grains and iron oxides micro-volumes.

межзерновым скольжением - дифференцированным перемещением зерен (гранул) относительно друг друга. Перечисленные особенности выражены также в инфраструктуре протрузии мел-палеогеновых песков и юрских глин, тектонически внедрившихся в моренные и флювиогляциальные отложения (см. рис. 11, в) 2 , а также характерны для гляциодислокаций и других регионов [Lavrushin, Chugunny, 1982].

Установлены три варианта формирования и фиксации инфраструктуры зернистых сред и их объемного течения за счет межзернового скольжения (рис. 12, б).

(a) - процесс начинается с образования кливажных сколов, ориентированных косо к напластованию пород. Часто сколы зарождаются по направлению косой седиментационной слоистости и, проникая в вышележащие слои, формируют структурную «косую полосчатость», рассекающую пласты кварцитопесчаников. Вдоль трещин скалывания происходит концентрация окислов железа. При внутрипластовом течении элементарные объемы вещества (зерна, агрегаты зерен, скопления окислов железа) испытывают дифференциальное смещение, вследствие чего первично-субпараллельные полоски окислов железа приобретают форму складок продольного течения, таковыми, в сущности, не являющихся. В дальнейшем послойный кливаж сланцеватости сечет псевдоскладки и изгибы и смещает границы слойков, которые становятся неровными, зазубренными, напоминая стилолиты. На границах кварцевых зерен возникают структуры растворения и микростилолитовые швы. Образуются послойные срывы и преломление

\footnotetext{
${ }^{2}$ Термин «протрузия» введен Ч. Лайелем для обозначения геологических тел, которые в твердом состоянии были выдвинуты (выжаты) в
} вышележащие слои под действием тектонических сил. Широко используется в современной научной терминологии. 
ожелезненных полосок, что свидетельствует о дифференцированном движении вещества.

(б) - межзерновое скольжение наложено на диагенетические образования типа колец Лизеганга, которые формируются в результате динамической разгрузки блоков при их образовании и до деформации течения. Железистое вещество образует тонкие лентообразные выделения, параллельные границам блоков, микрокливажным сколам и соответствующей им сланцеватости. Там, где фрагменты колец поперечны к простиранию кливажа и сланцеватости, ширина полос ожелезнения увеличивается и они имеют неровный зубчато-волнистый рисунок, отвечающий амплитудам смещения по каждой из микрокливажных плоскостей (см. также рис. 9).

(в) - полосчатость и внутрислоевая деформация одновременны и связаны парагенетически. В процессе течения происходит механическая и метаморфическая дифференциация вещества с отгонкой окислов железа и одновременным оформлением «псевдоскладок» послойного течения. Этот механизм, вероятно, проявляется в качестве составляющей вариантов (а) и (б).

Таким образом, несмотря на различия в возрасте, структурной позиции и условиях формирования, процесс 3D-деформации в метаосадочных породах проточехла Карельского массива и рыхлых гляциальных отложениях Поволжья протекает по схожему сценарию и осуществляется в виде межзернового скольжения, при котором каждый элементарный объем (гранула) испытывает перемещение, относительно независимое от соседствующих объемов. Набор формирующихся при этом структурных форм отвечает парагенезу вязкопластического течения [Miller, 1997; Nicolas, 1992].

\section{2. Постмагматическая деформация гранитов}

Около 50-80 \% объема коры континентов занимают гранитоиды. В контексте обсуждаемого вопроса наиболее информативны средне- и крупнокристаллические калишпатовые и двуполевошпатовые граниты, которые во многом определяют структуру и реологию верхней коры (см., например [Areshev et al., 1997; Leonov, 2008; Leonov et al., 2018; Przhiyalgovsky et al., 2014; Sitdikova, Izotov, 2003; Foose, 1976]). В качестве примера рассмотрим строение двух гранитных массивов, а затем дадим обобщенную характеристику постмагматической инфраструктуры гранитных тел.

Кумсинский гранитогнейсовый купол. На юго-востоке Балтийского щита расположен выступ архейского фундамента (Уницкий массив) [Kratts, 1963] (см. рис. 6, пункт 4 на врезке; рис. 13), обрамленный отложениями палеопротерозойского проточехла. Проточехол прорван цепочкой линзовидных куполов-антиклиналей, ядра которых сложены гранитогнейсами нижнего архея, а крылья - андезибазальтами сумия, сариолийскими элювиально-делювиальными брекчиями и шлейфами микститоподобных конгломератобрекчий сариолия и вулканогенно-осадочными толщами ятулия (рис. 14, 15) [Kolodyazhny et al., 2000; Leonov et al., 2001; Glushanin, et al., 2011]. Гранитогнейсовые поднятия выражены в рельефе как поверхности фундамента, так и земной поверхности. Купола морфологически контрастны, характеризуются крутым или запрокинутым залеганием обрамляющих гранитоидные ядра пластов, зачастую оконтурены взбросо-надвигами. Одним из куполов является Кумсинский купол, в пределах которого структурные преобразования фундамента проявлены на микро-, мезо- и макроуровнях.

Породы раздроблены и пронизаны эшелонированными зонами скалывания шириной от 1 см до 1-2 м, выполненными бластокатаклазитами и бластомилонитами с зеркалами скольжения и минеральной линейностью. Перекрещивание сколов приводит к образованию крупных (0.5-2.5 м) и мелких (см) блоков, имеющих форму ромбоэдров или параллелепипедов с длинными осями, ориентированными субвертикально или в виде структурного веера с падением сколов навстречу друг другу под углами 40-80. Блоки (см. рис. 14) смещены относительно друг друга. Пронизывающие граниты жильные тела и дайки также будинированы, разорваны, изогнуты. Некоторые блоки имеют изогнуто-линзовидную форму и деформированы пластически (см. рис. 14). На концах линз образуются хлорит-биотитовые дворики давления, указывающие на перемещение материала снизу вверх. Многочисленны трещинки отрыва, перпендикулярные общему удлинению и заполненные поперечно ориентированными чешуйками серицита и хлорита. В межблоковых объемах (интерфейсных зонах) наблюдается ориентированное расположение линзочек кварца, чешуек деформированного и хлоритизированного биотита, удлинение минеральных зерен, растащенных по системам микросколов и зонам трансляционного скольжения. Накопление продуктов разложения гранитов в межзерновых пространствах ослабляет сцепление минеральных зерен и облегчает их относительное смещение. Таким образом, инфраструктура ядра Кумсинского купола представляет собой тектоническую брекчию (рис. 14, 15) - продукт объемной деформации гранитов пластически-хрупкого типа.

Гранитогнейсовые купола обрамлены грубокластическими образованиями, для которых реконструируется [Kolodyazhny et al., 2000] следующая вертикально-латеральная последовательность напластования: тектонически дезинтегрированные граниты $\rightarrow$ кора физического (в том числе механического) выветривания $\rightarrow$ элювий (неперемещенный и перемещенный) $\rightarrow$ хаотические гранитоидные брекчии $\rightarrow$ гранитные глыбовые конгломераты $\rightarrow$ полимиктовые конгломераты с окатанными гальками гранитов и иных пород (рис. 15). Такие взаимоотношения объясняются активным ростом куполов в период накопления сариолийских комплексов. Радиоизотопные данные свидетельствуют о неоднократной ремобилизации гранитов на свекофеннском этапе тектоно-метаморфической активизации [Kolodyazhny et al., 2000]. Судя по выраженности в релье$\phi е$, особенностям инфраструктуры и соотношению с комплексами проточехла, граниты образуют выжатое 


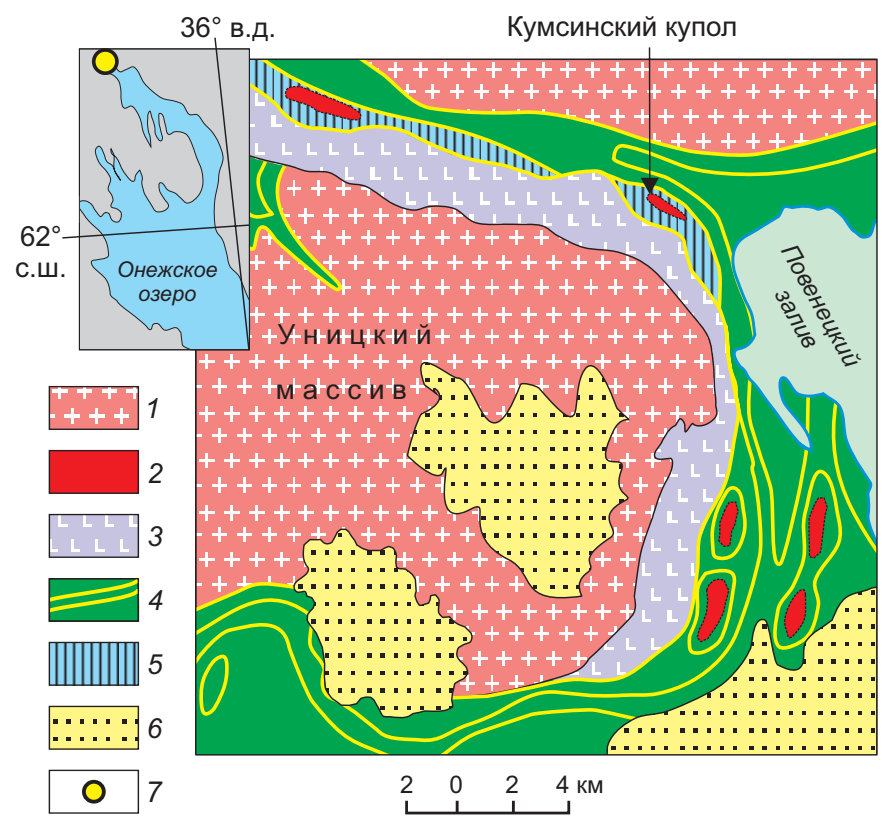

Fig. 13. Гранитные купола в структуре Северо-Западного Прионежья (по [Leonov et al., 2001]).

1-2 - комплексы раннеархейского фундамента: 1 - основные выходы, 2 - в ядрах частных антиклиналей и протрузий; 3-5 позднеархейские и раннепротерозойские образования: 3 - лопий, 4 - ятулий, 5 - сариолий; 6 - четвертичные отложения; 7 расположение Кумсинского купола на карте-врезке.

Fig. 13. Granite domes in the structure of the northwestern Onega region (after [Leonov et al., 2001]).

1-2 - complexes of the Early Archean basement: 1 - main outcrops, 2 - in the cores of anticlines and protrusions; 3-5 - Late Archean and Early Proterozoic formations: 3 - Lopian complex, 4- Yatulian complex, 5 - Sariolian complex; 6 - Quaternary deposits; 7 - location of the Kumsa dome in the inset map.

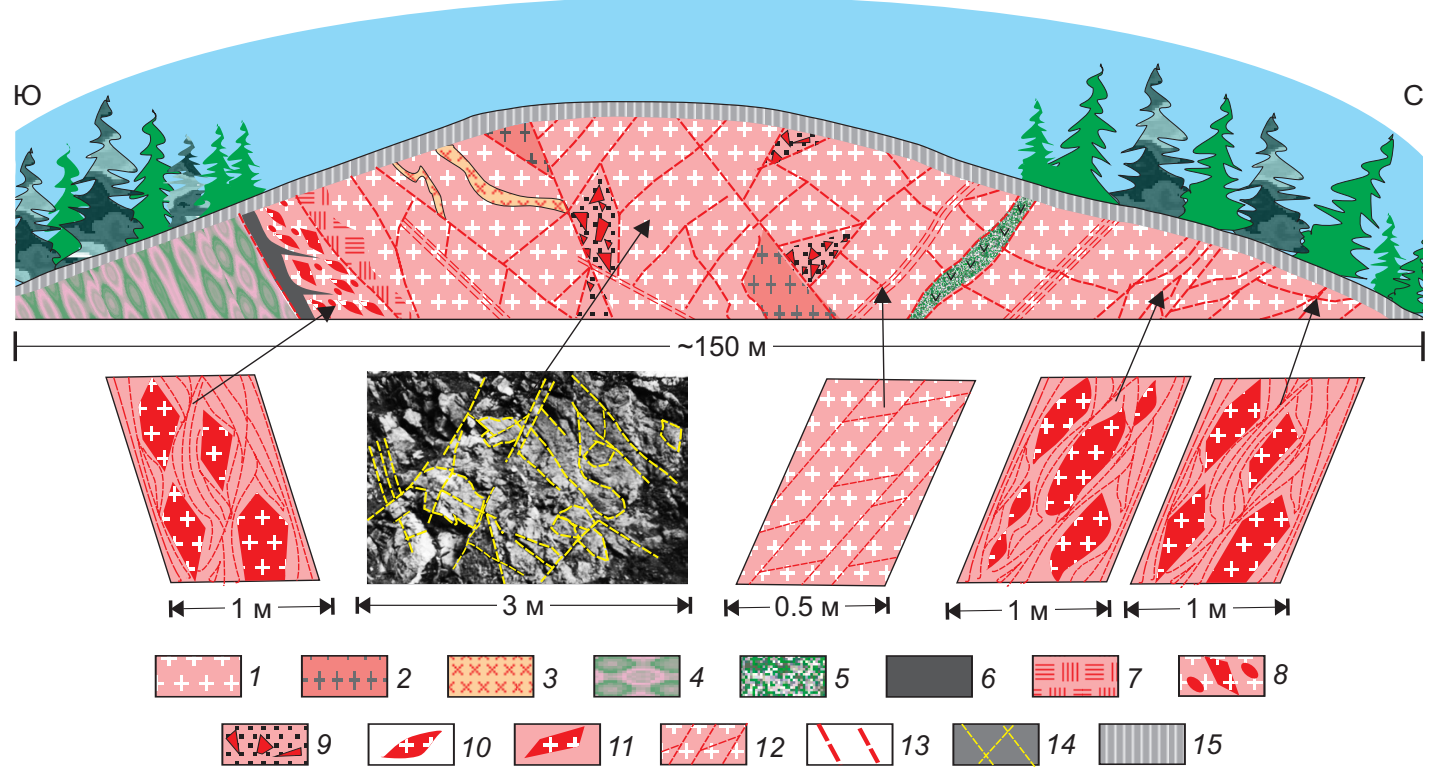

Рис. 14. Строение Кумсинского купола (по [Kolodyazhny et al., 2000; Leonov et al., 2001]).

1-3 - породы архейского фундамента: 1 - граниты, 2 - фрагменты кварцевых диоритов, 3 - пегматиты; 4 - сариолийские рассланцованные конгломераты; 5 - дайки диабазов; 6 - альбит-биотитовые метасоматиты; 7 - гранитный дресвяник; 8 - глыбовые гранитные конгломератобрекчии; 9 - тектонические брекчии; 10-12 - дезинтегрированные граниты с элементами рассланцевания: 10 - с линзовидными фрагментами пород, 11 - с ромбоэдровидными фрагментами пород, 12 - с ромбовидно-блочной делимостью; 13 - разломы; 14 - сетка разломов на фотографии; 15 - почвенный слой.

Fig. 14. Structure of the Kumsa granite dome (after [Kolodyazhny et al., 2000; Leonov et al., 2001]).

1-3 - Archean basement complexes: 1 - granites, 2 - diorites fragments, 3 - pegmatites; 4 - sheared Sariolian conglomerates; 5 - dikes of diabases; 6 - albite-biotite metasomatites; 7 - granitic tresvant; 8 - granitic block conglomerate-breccia; 9 - tectonic breccia; 10-12 disintegrated granites with foliation elements: 10 - with lens-shaped rock fragments, 11 - with diamond-shaped rock fragments, 12 with rhomboid-block divisibility; 13 - faults; 14 - fault network in the photo; 15 - soil layer. 
с глубины тело протыкания типа протрузии (рис. 15) [Zykov, 1997, 1999; Kolodyazhny et al., 2000; Leonov et al., 2018].

Тугнуйский «горст» (Западное Забайкалье). На территории Западного Забайкалья расположены впадины, выполненные мезозойскими и кайнозойскими вулканогенными и осадочными отложениями. Впадины чередуются с поднятиями (хребтами), ядра которых представлены породами гранитно-метаморфического фундамента. Одним из таких поднятий является горстообразный выступ, разделяющий Тугнуйскую впадину на две котловины: северную - собственно Тугнуйскую и южную - Сухаринскую (рис. 16, а, б).

Это поднятие - «горст» [Ermikov, 1994], сложено граносиенитами и двуполевошпатовыми гранитами позднеджединского комплекса $\left(\mathrm{C}_{2}\right)$ с многочисленными включениями габброидов моностойского $\left(\mathrm{Pz}_{1}\right)$ и сиенитов и лейкогранитов соготинского $\left(\mathrm{P}_{2}\right)$ комплекса, а также андезибазальтами, сходными с породами ичетуйской $\left(\mathrm{J}_{1-2}\right)$ свиты. Тугнуйский горст представляет собой относительно приподнятую над общим уровнем рельефа морфоструктуру, вытянутую в соответствии с общим 3Ю3-ВСВ простиранием структур Забайкалья. Протяженность поднятия составляет несколько десятков километров, ширина до 4-5 км.

Гранитоиды интенсивно дезинтегрированы (рис. 16, в, г), вплоть до полного раздробления и катаклаза минеральных зерен (рис. 16, д). Кварц имеет волнистое погасание, а зерна - линзовидную форму. Зерна кварца преобразованы в гранобластовый агрегат. Включения гранулированного кварца обычно расположены между полевошпатовыми зернами, которые раздроблены, катаклазированы, серицитизированы и пелитизированы. Значительные объемы гранитов потеряли внутреннюю связность и превращены в тектоническую брекчию (псевдодресвяник) или дезинтегрированы до песка. В этой рыхлой массе сохранились отдельные блоки гранитов, сохранивших первичные структуры и текстуры. Блоки имеют овальную, слегка линзовидную или неправильно-округлую форму, расположены хаотично, но их длинные оси часто субпараллельны и расположены весьма круто (от 40 до 90). Переходы от относительно монолитных блоков и линз к катаклазированной основной массе иногда резкие, иногда нечеткие, с постепенным уменьшением степени раздробленности. Тонкая трещиноватость и рассланцованность нарастают к центру интерфейсных зон, в центральной части которых возникает единая разломная плоскость. Трещины и небольшие разрывы часто приурочены к границам монолитных блоков и раздробленной основной массы. Объем раздробленной основной массы пород сравним с объемом заключенных в матриксе монолитных фрагментов или превышает его.

Общая структура массива хаотичная, петельчатолинзовидная. В массе гранитного катаклазита присутствуют хаотично расположенные линзовидные тела пород основного состава, которые милонитизированы, развальцованы, хлоритизированы. Они, вероятно, являются фрагментами даек, прорывавших граниты. Наблюдаются и обратные соотношения, когда округлые блоки и шары гранитного состава обволакиваются матриксом из рассланцованных основных пород. В целом
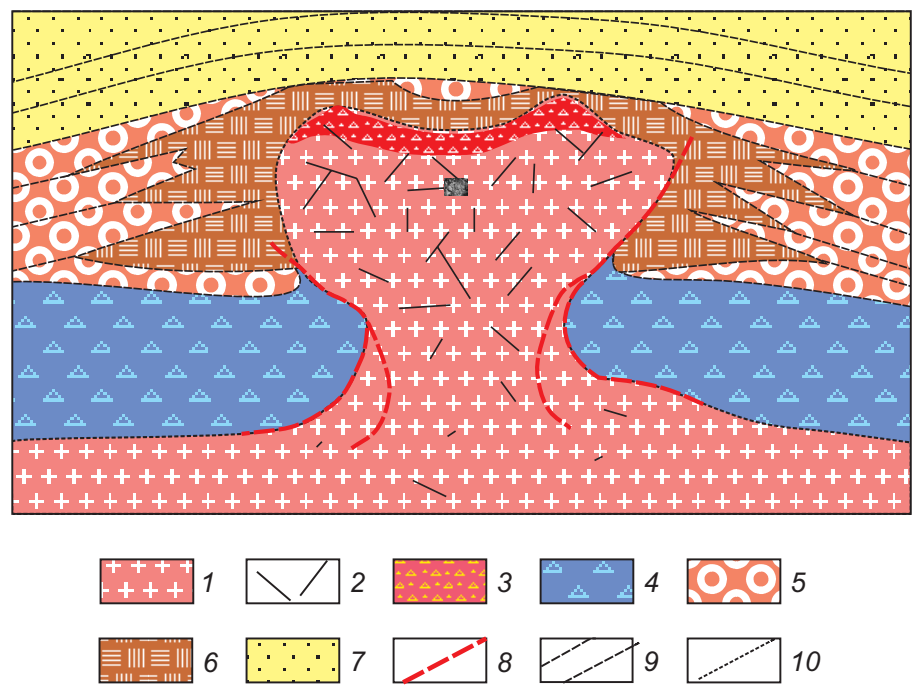

Рис. 15. Реконструкция Кумсинского гранитного купола и инфраструктура гранитов (по [Kolodyazhny et al., 2000], с дополнениями).

1 - архейские граниты; 2 - архейские граниты, раздробленные; 3 - гранитная дресва - кора выветривания; 4 - сумийские вулканогенно-осадочные отложения; 5 - сариолийские глыбовые конгломераты; 6 - грубообломочные гранитные брекчии; 7 - ятулийские осадочные отложения; 8 - разломы; 9 - линии напластования; 10 - протрузивный контакт.

Fig. 15. Reconstruction of the Kumsa granite dome and the infrastructure of granites (after [Kolodyazhny et al., 2000]).

1 - Archean granites; 2 - crushed Archean granites; 3 - granitic tresvant - weathering crust; 4 - Sumian volcano-sedimentary deposits; 5 - Sariolian boulder conglomerates; 6 - coarse-breaking granite breccia; 7 - Yatulian sediment deposits; 8 - faults; 9 - stratification lines; 10 - protrusive contact. 
породы Тугнуйского «горста» имеют облик гранитнобазитового меланжа.

Палеозойские граниты выведены на один гипсометрический уровень с базальтами ичитуйской $\left(J_{1-2}\right)$ свиты (рис. 16, б), а в своей апикальной части граниты, образуя морфологическую аномалию, расположены на 10-20 м выше, чем соседствующие с гранитами базальты. По инфраструктуре, степени переработки пород и взаимоотношению с окружающими образованиями Тугнуйский «горст» отвечает категории кристаллических протрузий, формирование которых связано с 3D-текучестью пород в условиях вязкостной инверсии [Leonov, 2008; Leonov et al., 2018; Patalakha, 1971].

Приведем теперь обобщенную характеристику постмагматической деформации гранитов, основанную на изучении многочисленных объектов [Leonov et al., 2018]. Граниты в той или иной степени испытали деформацию на постмагматической стадии их существования и интенсивно дезинтегрированы на мега-, макро-, мезо- и микроуровнях (см. рис. 3, 4, 5, 14,16; рис. 17, 18, 19, 20,21).

Интерфейсное пространство заполнено микробрекчиями, микрокатаклазитами и зонками рассланцевания, которые маркируют границы доменов мезо- и макроуровней. Деформация пород в интерфейсных зонах существенно интенсивнее, чем в разделяемых ими фрагментах (см. рис. 19).
Изучение постумной тектоники свидетельствует о рассеянном характере полей напряжений в пределах породных массивов. Внутренние деформации не нарушают сплошность ограничивающей массив поверхности, и массивы деформируются как единое квазиконсолидированное тело, но в то же время происходит относительно независимое деформирование его фрагментов (кусков, блоков) и их дифференциальное перемещение и вращение, на что указывает различная ориентировка систем трещин и полей напряжений в разных блоках и доменах (см. рис. 4, 20).

Интенсивно раздробленные и разрыхленные граниты, которые легко подвергаются разрушению и выветриванию, доминируют над общим уровнем рельефа, образуя геоморфологические аномалии. Выдвижение в верхние горизонты коры гранитных «тел протыкания», сложенных раздробленными (разрыхленными) породами, связано с объемным катакластическим блочно-гранулярным течением породных масс.

С некоторой условностью можно говорить о трех группах факторов, ответственных за постмагматическую дезинтеграцию гранитов: (1) - факторы прототектонические (автометасоматоз, гидротермально-пневматолитовые процессы, контракционная усадка, тектонокессонный эффект, динамическая рекристаллизация); (2) - факторы экзогенные (физическое выветривание);
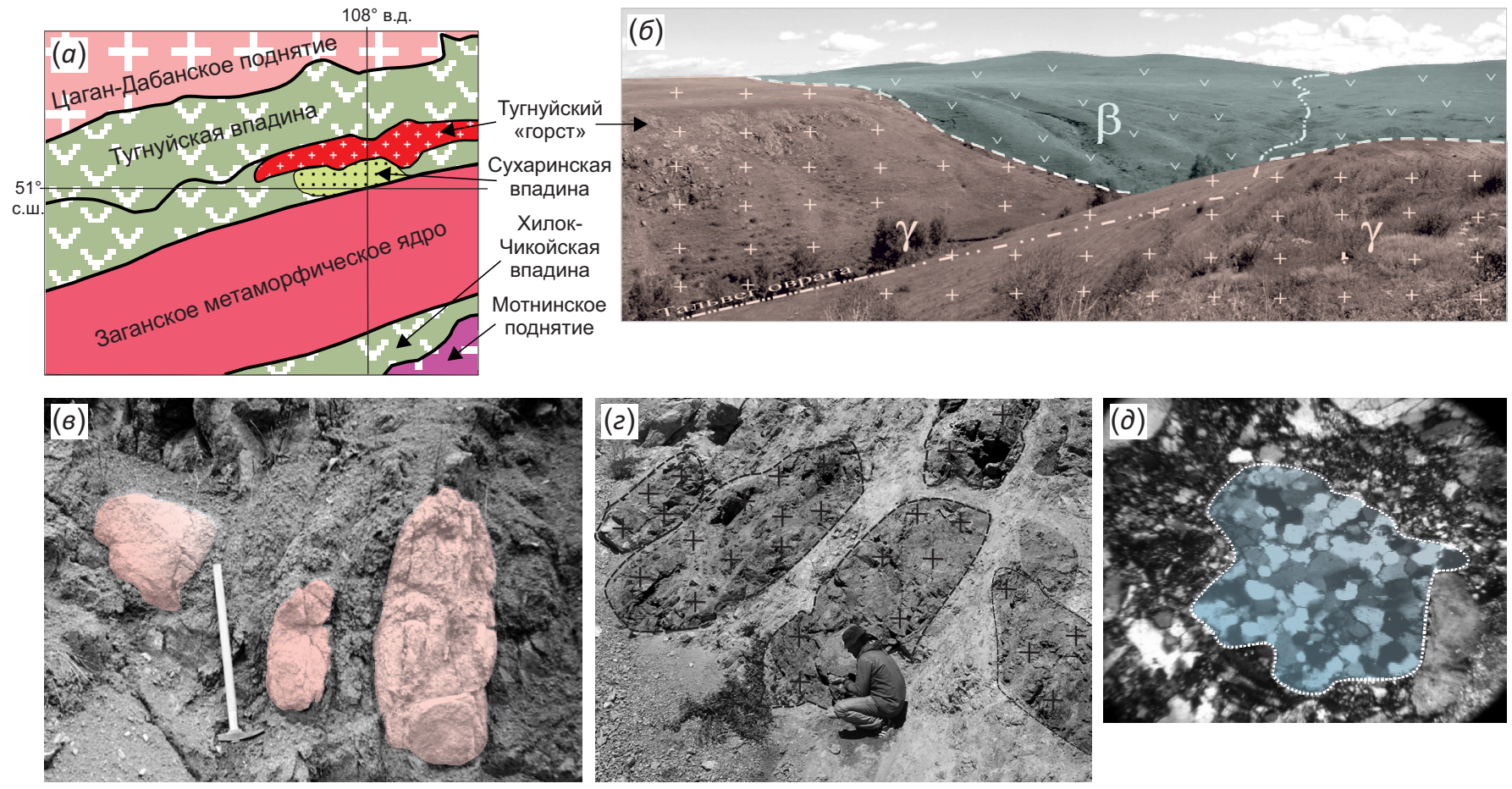

Рис. 16. Граниты Тугнуйского «горста» (объяснения в тексте).

(a) - положение Тугнуйского «горста» в структуре Западного Забайкалья; (б) - взаимоотношение плотных монолитных базальтов ичетуйской свиты $\left(\mathrm{J}_{1-2}\right)$ и катаклазированных гранитов $\left(\mathrm{C}_{2}\right) ;(\theta, 2)$ - катаклазированные граниты Тугнуйского горста; $(\partial)-$ микрофотография, точечной линией выделено катаклазированное зерно кварца.

Fig. 16. Granites of the Tugnui "horst" (explanations in the text).

(a) - position of the Tugnuy "horst" in the structure of the Western Baikal region; (б) - relationship between dense monolithic basalts (Ichetuy suite, $\left.\mathrm{J}_{1-2}\right)$ and cataclastic granites $\left(\mathrm{C}_{2}\right) ;(6,2)$ - cataclastic granites of the Tugnuy horst; $(\partial)$ - microphoto (a cataclased quartz grain is marked with a dotted line). 


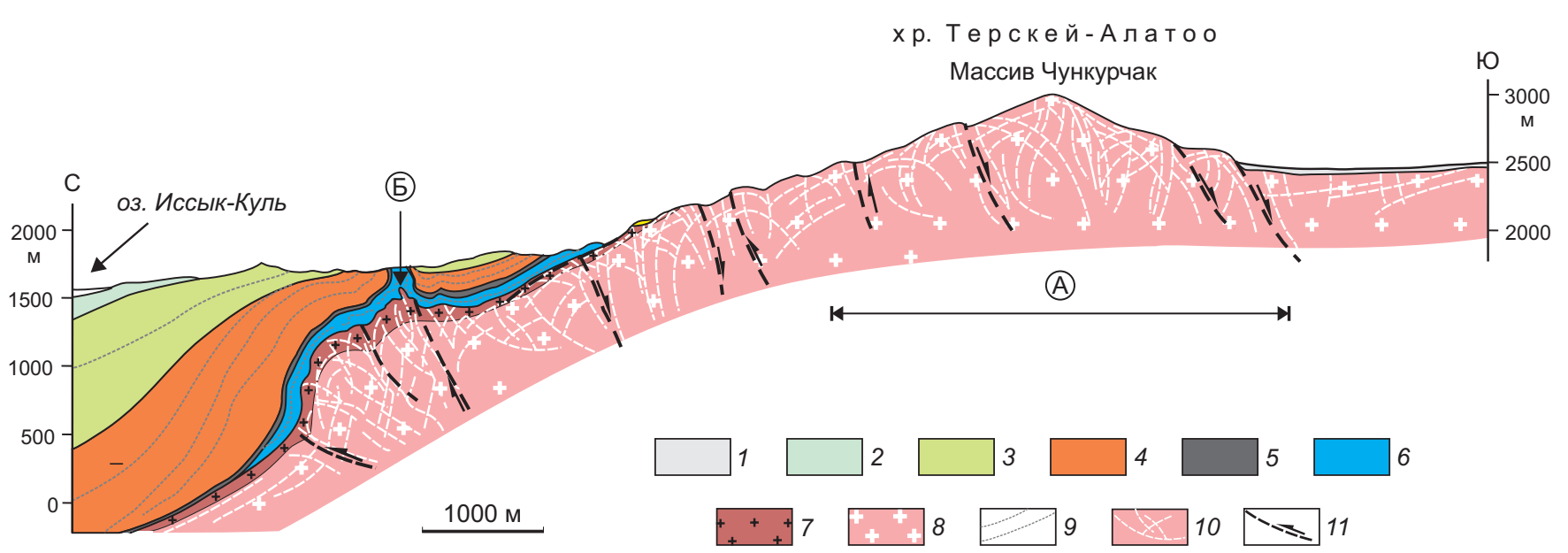

Рис. 17. Поперечный разрез через зону сочленения Иссык-Кульской впадины и хребта Терскей-Алатоо.

1 - четвертичные отложения; 2-5 - отложения палеогена - неогена: 2 - шарпылдагская свита, 3 - иссык-кульская свита, 4 киргизская свита, 5 - коктурпакская свита; 6 - нижняя юра; 7 - кора выветривания по породам фундамента; 8 - палеозойский фундамент; 9 - условные горизонты осадочного чехла; 10 - разломно-трещинная структура фундамента; 11 - главные разломы и направление смещения крыльев. А - см. рис. 20; Б - см. рис. 21.

Fig. 17. Cross-section of the junction zone of the Issyk-Kul depression and Terskay-Alatoo ridge.

1 - Quaternary deposits; 2-5 - Paleogene-Neogene deposits: 2 - Sharpyldag suite, 3 - Issykkul suite, 4 - Kyrgyz suite, 5 - Kokturpak suite; 6 - Lower Jurassic; 7 - weathering crust on the basement rocks; 8 - Paleozoic basement; 9 - conditional horizons of the sedimentary cover; 10 - faulted-fractured structure of the basement; 11 - main faults and displacement direction. A - see Fig. 20; $\mathrm{B}$ - see Fig. 21.

(a)

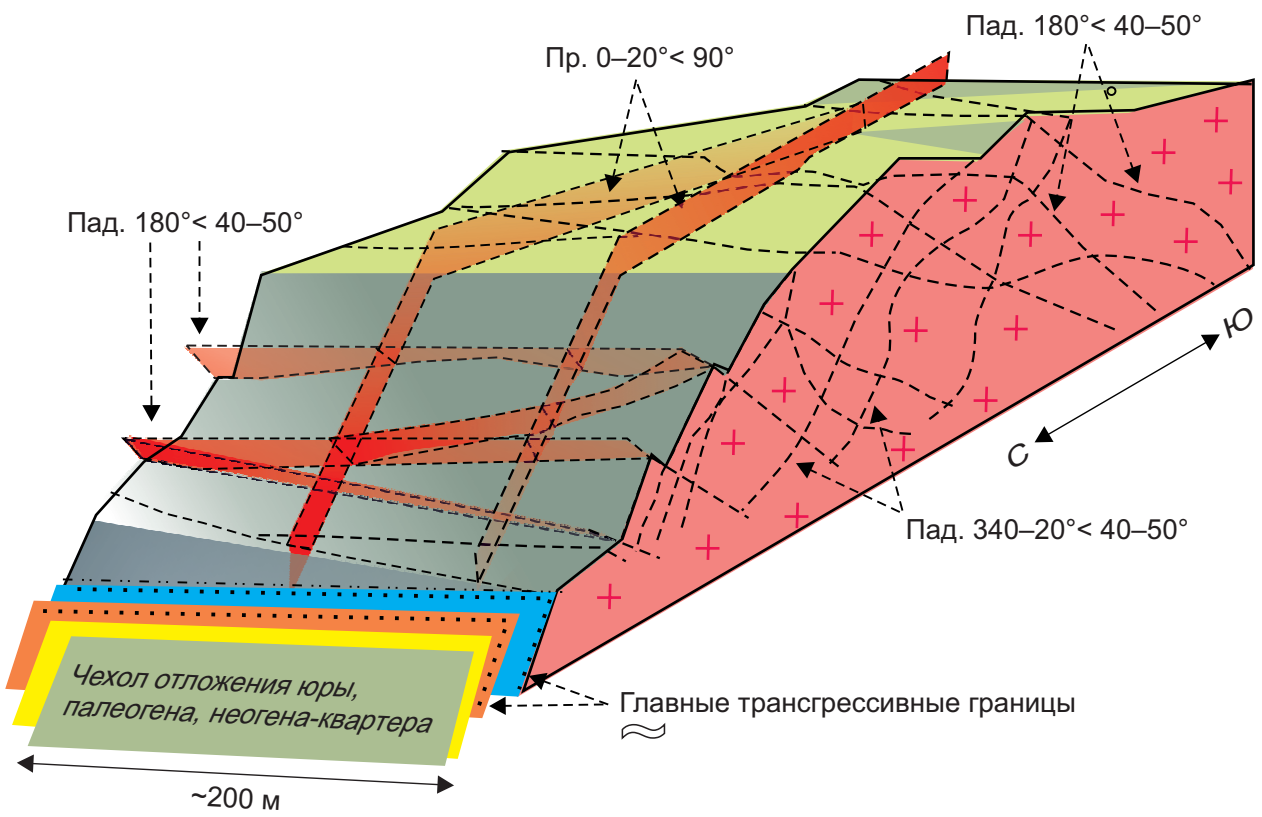

(6)

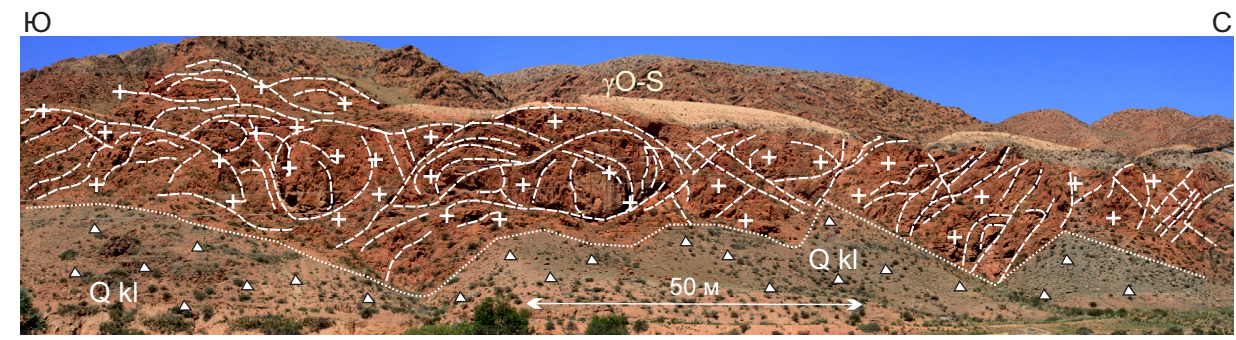

Рис. 18. Тектоническая структура гранитов фундамента Северного Тянь-Шаня.

(a) - линзовидно-блоковая макроструктура (район пос. Каджи-сай); (б) - блоково-овоидная мезо- и макроструктура (южный борт Кочкорской впадины).

Fig. 18. Tectonic structure of the North Tien Shan basement granites.

(a) - lens-block macrostructure (Kaji-sai area); (б) - block-ovoid meso- and macrostructures (southern side of the Kochkor depression). 
(3) - факторы тектонические. Факторы первой и второй группы, сами по себе или в различных сочетаниях, не обеспечивают значений пористости, которые зафиксированы в природных объектах, например в гранитах, содержащих месторождения углеводородов. Фактор тектонический, напротив, существенно влияет на процесс постмагматической дезинтеграции гранитных тел [Leonov et al., 2018].

\section{3. ОБСУЖДЕНИЕ МАТЕРИАЛА: МЕХАНИКА ГРАНУЛИРОВАННЫХ СРЕД И УСТАЛОСТНОЕ РАЗРУШЕНИЕ ГОРНЫХ ПОРОД}

Выше было показано, что горные породы обладают объемной подвижностью (текучестью), которая зафиксирована в их инфраструктуре, в изменении формы и объема геологических тел, в образовании специфических морфоструктур. Известно [Azhgirey, 1966; Beroush,
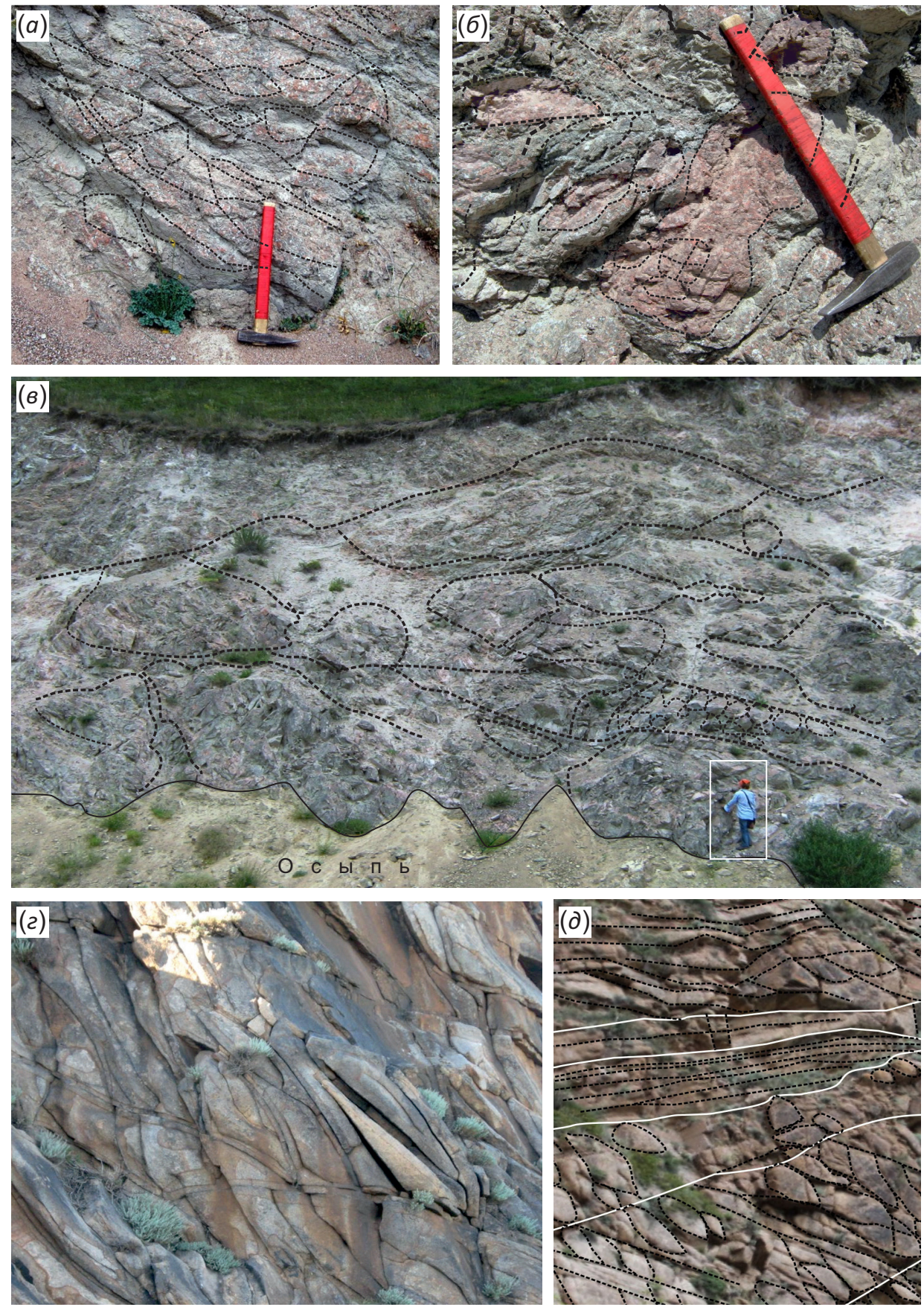

Рис. 19. Тектоническая делимость гранитов макро- и мезомасштаба (объяснения в тексте).

$(a, 6,8)$ - граниты (O-S) Северного Тянь-Шаня, долина р. Иссык-Ата; (2) - граниты массива Дзурамтай (Южная Монголия); (д) граниты (O-S) массива Чонкурчак (хр. Терскей-Алатоо, СеверныйТянь-Шань).

Fig. 19. Tectonic divisibility of granites in macro- and mesoscales (explanations in the text).

$(a, 6,8)$ - granites $(0-S)$ of North Tien Shan (Issyk-Ata river valley); (2) - granites of the Dzuramtay massif (South Mongolia); $(\partial)-$ granites (O-S) of the Chongkurchak massif (Terskay-Alatoo, North Tian Shan). 
1991; Gol'din, 2002; King, 1967; Patalakha, 1971; Bradschaw et al., 1967], что для того, чтобы твердое тело изменило свою форму, а его поверхность испытала изгиб без разрыва сплошности, должно произойти пространственное перераспределение элементарных составляющих деформируемого объема или эти составляющие должны изменить свою форму, что возможно либо при высоких Р-Т параметрах либо при ослаблении (или потере) внутренней связности и возникновении (или первичном существовании) дискретной гранулярной s. l. структуры (см. рис. 1).

Горные породы в естественном залегании находятся в сложнонапряженном состоянии и деформированы под действием различных по своей природе сил. Во многих случаях стиль деформаций свидетельствует о внутренней 3D-подвижности (текучести) породных масс, которая обеспечивается дезинтеграцией пород и возникновением дискретной инфраструктуры. Дезинтеграция проявляется на различных масштабных уровнях и варьируется от наночастиц и тончайшего катаклазита (см. рис. 5) до гигантских массивов (см. рис. 2), в совокупности образующих линзовидно-блоковую мегабрекчию. Процесс сопровождается потерей внутренней связности (разрыхлением) горных пород [Ruzhich, 1997; Sobolev et al., 2016; Gatinsky et al., 2018].

Исходя из общих соображений, можно полагать, что такие породные субстанции будут вести себя в соответствии с законами, отражающими их физическую сущность, т.е. законами механики блочно-гранулированных сред или мезомеханики. Дальнейшие рассуждения

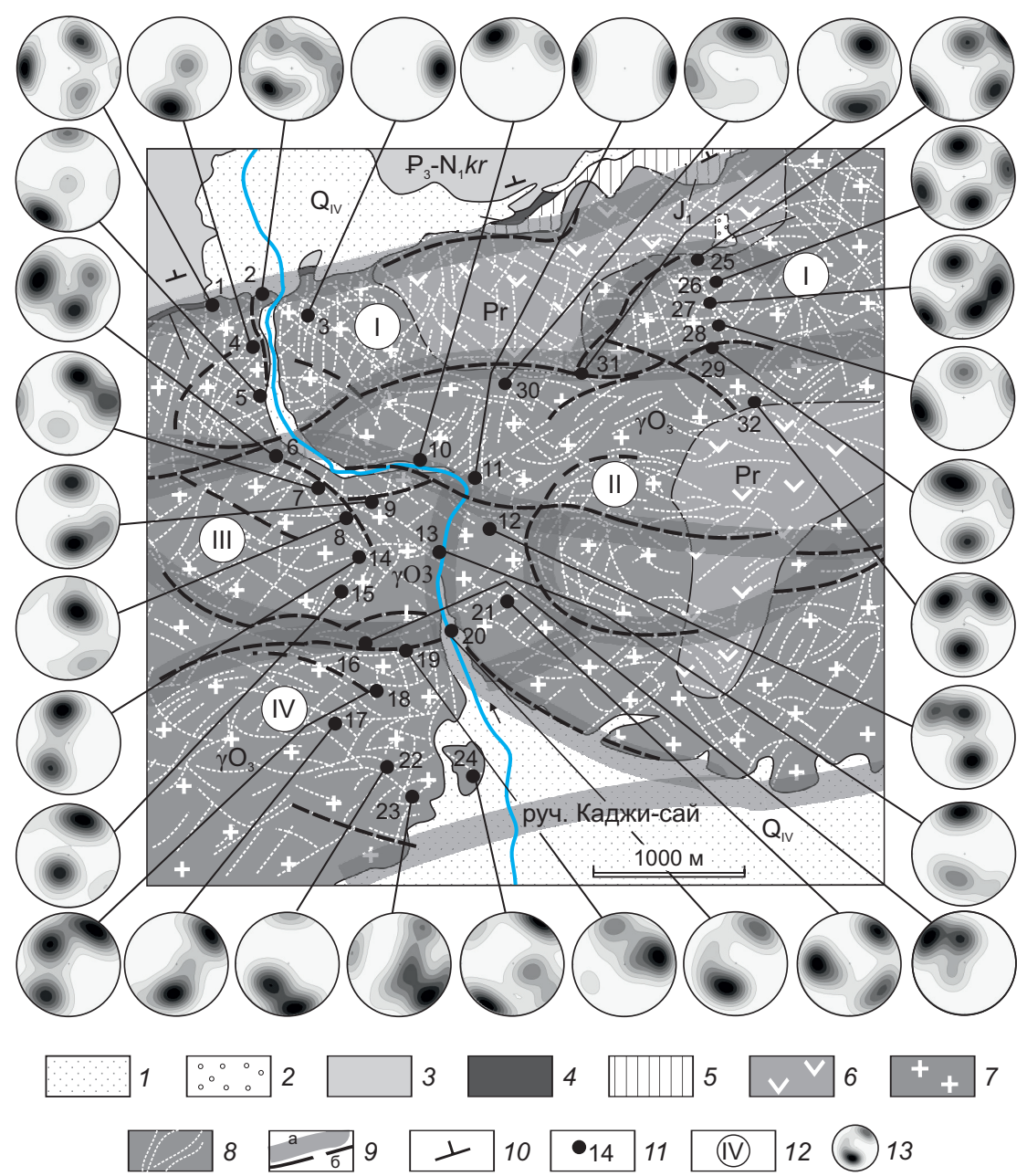

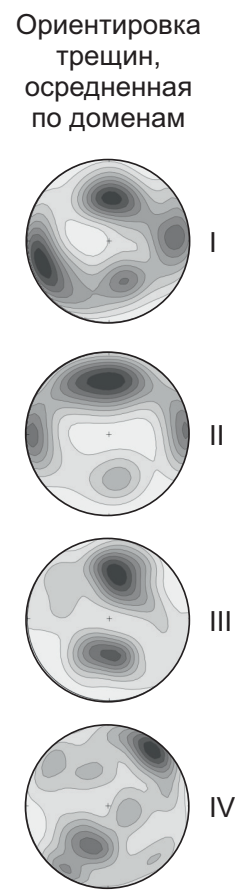

Осреднение

по зонам мегалинеаментов

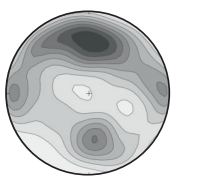

Рис. 20. Структура гранитов массива Чонкурчак [Leonov et al., 2018].

1 - коллювий и пролювий; 2 - шарпылдакская свита; 3 - киргизская серия; 4 - коктурпакская серия; 5 - нижняя юра; 6 - протерозой; 7 - граниты верхнего ордовика; 8 - трещины и разломы (по данным дешифрирования космоснимков); 9 - деструктивные зоны в фундаменте: а - линеаменты мегауровня, б - разломы макроуровня; 10 - элементы залегания; 11 - точки статистических замеров трещиноватости; 12 - номера доменов в гранитах; 13 - стереограммы плотностей полюсов трещин (проекция Шмидта, нижняя полусфера).

Fig. 20. Structure of granites of the Chonkurchak massif [Leonov et al., 2018].

1 - colluvium and proluvium; 2 - Sharpyldag suite; 3 - Kyrgyz suite; 4 - Kokturpak suite; 5 - Lower Jurassic; 6 - Proterozoic; 7 granites (upper Ordovician); 8 - fractures and faults (identified from space images); 9 - zones of destruction in the basement: a megascale lineaments, 6 - macroscale faults; 10 - layering elements; 11 - points of statistical measurements of fractures and cracks; 12 - numbers of domains in granites; 13 - fracture pole density stereograms (Schmidt projection, lower hemisphere). 
будут основаны на данных авторов статьи и опубликованных материалах ${ }^{3}$. Гранулированная среда - это совокупность соприкасающихся друг с другом твердых доменов (зерен, блоков, связных объемов), пространство между которыми заполнено менее вязкой субстанцией - флюидом, воздухом, диспергитами, тектоническими брекчиями, микрокатаклазитами и пр. При этом внутренняя связность вещества условно монолитных доменов выше, чем связность доменов друг с другом (рис. 22).

К гранулированным средам относятся сыпучие образования, а также «условно монолитные» горные породы с ослабленными межзерновыми связями (брекчии, граниты, метаморфические породы [Eshelby, 1963]).Кроме того, горные породы при определенных условиях подвержены вторичной грануляции, что проявляется в брекчировании, катаклазе, меланжировании, в ослаблении межзерновых и междоменных связей.

Физические свойства гранулированных сред отличаются от свойств твердых тел, жидкостей и газов [Bobryakov et al., 2010; Yaeger, Nagel, 1996]. Ансамбль взаимодействующих частиц представляет собой нелинейную диссипативную систему, а самоорганизация системы обусловливает такие эффекты коллективного поведения частиц, как формирование блочных структур, локализация скольжения, скачкообразная неустойчивая деформация.... «Твердое» тело, приобретая гранулированную структуру, приобретает свойства «вязкотекучего» тела и способность к реидной деформации. Объемная подвижность - фундаментальное свойство блочной среды [Kocharyan, Spivak, 2003]. Гранулярное течение может не иметь структурного выражения, что

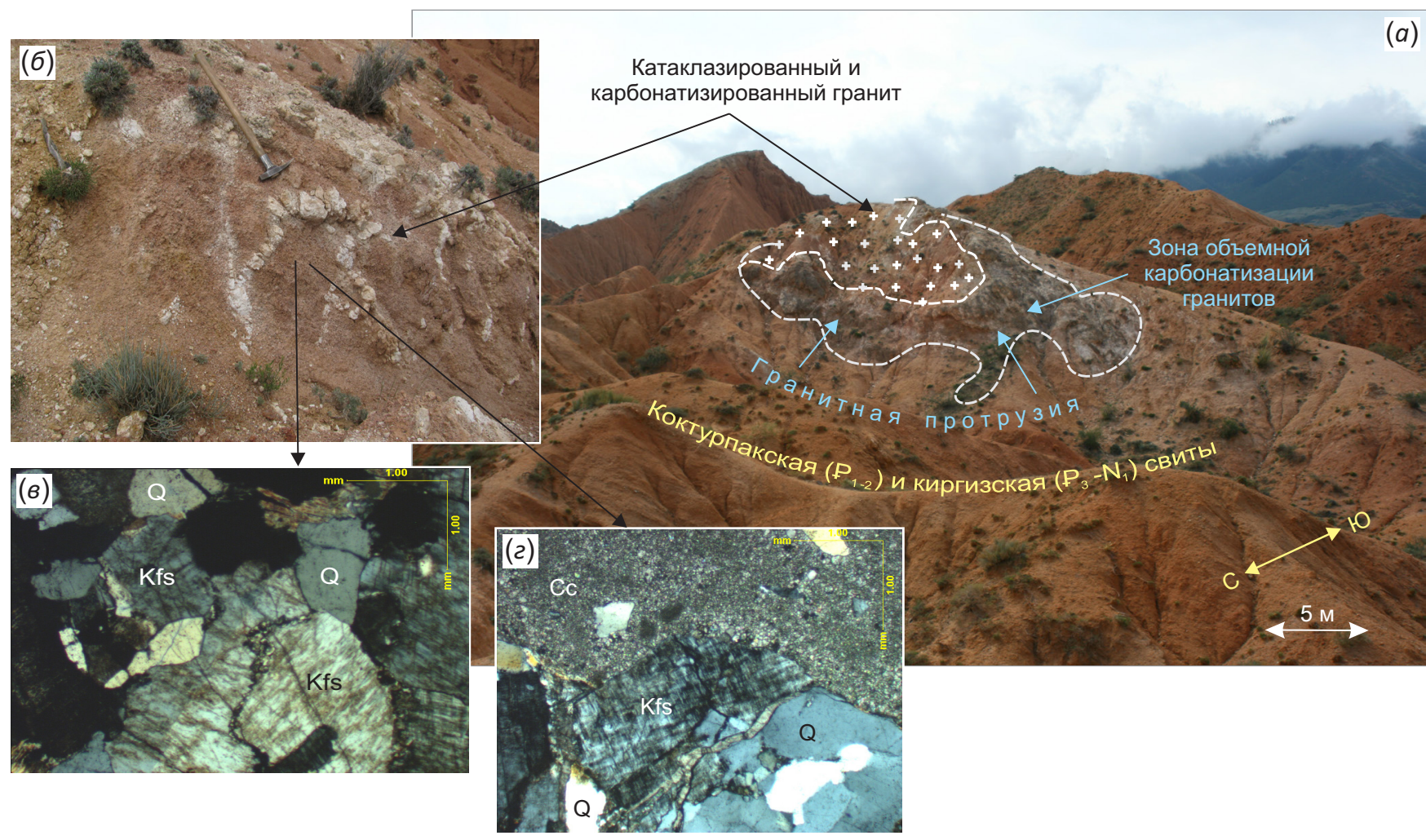

Рис. 21. Гранитная протрузия Кызыл-Булак (см. также рис. 17; выход гранитов на дневную поверхность расположен западнее профиля).

(a) - общий вид и детали строения; (б) - гранитный катаклазит и кальцит-каолиновые жильные выделения, подчеркивающие линзовидно-сетчатую структуру дезинтегрированных гранитов; ( 8 ) - гранитный дресвяник с мелкокристаллическим кальцит-каолиновым матриксом; (2) - фрагмент слабоизмененного трещиноватого гранита в катаклазированном гранитном матриксе (микрофотографии и интерпретация Е.В. Лаврушиной, из [Leonov et al., 2018]).

Fig. 21. The Kyzyl-Bulak granite protrusion (see also Fig. 17. Granites on the day surface are located west of the profile).

(a) - general view and details of the structure; (б) - granitic cataclysite and calcite-kaolin veins, emphasizing the lenticular-mesh structure of disintegrated granites; ( 8 ) - granitic dredge with fine-crystalline calcite-kaolin matrix; (2) - fragment of slightly metamorphosed cracked granite within cataclastic granite matrix (microphoto and interpretation by E.V. Lavrushina, from [Leonov et al., 2018]).

${ }^{3}$ [Blekhman, 1994; Bobryakov et al., 2010, 2015; Bogdanov, Skvortsov, 1992; Budkov, Ostapchuk, 2013; Bykov, 1999; Garagash, 1982, 2006; Garagash, Nikolaevsky, 1989, 1994; Gol’din, 2002, 2005; Kaibyshev, 2000; Kaibyshev, Pshenichnyuk, 1999; Kosykh, 2008, 2015; Kocharyan, 2016; Kocharyan, Spivak, 2003; Lavrikov, Revuzhenko, 1994, 2015, 2017, 2019a, 2019b; Lavrikov et al., 2008; Parton, 2020; Polyakov, 2001; Pospelov, 1972; Psakhie et al., 2010; Revuzhenko, 2000, 2003, 2013; Revuzhenko et al., 1997; Ruzhich, 1997; Sadovsky, 1989; Sadovsky et al., 1988; Sibiryakov, Deev, 2008; Spivak, Kishkina, 2010; Stroganov et al., 2002; Hellan, 1988; Shvab, Martsenko, 2011; Behringer et al., 1999; Cambell, 1990; Drake, 1990; Jullien, 1992; Mehta, 1994; Sitharam, Nimbkar, 2000; Tejchman, Wu, 2007; Thompson, Grest, 1991; Yaeger, Nagel, 1992, 1996]. 
сходно с процессом течения жидких тел. 3D-деформацию таких субстанций можно фиксировать лишь при наличии реперов (примесей, новых минеральных фаз, механической сегрегации) или по рисунку возникших структурных форм. В одних и тех же динамических условиях тела с гранулярной инфраструктурой могут вести себя как хрупкие и как пластичные тела (рис. 23).

В кристаллических породах при начальном нагружении проявляется и упругая, и пластическая деформация. Вязкое катакластическое течение становится возможным после хрупкого разрушения, т.е. после фрагментации среды на блоки и резкого понижения объемной вязкости пород. Пластическая деформация фрагментированной среды происходит в результате проскальзывания «жестких» доменов относительно друг друга. Физическое моделирование показало, что при величине угла сдвига больше некоторого критического значения (предельного угла сдвига) образуются поверхности (a)

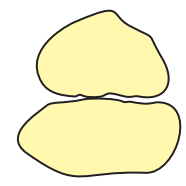

(б)

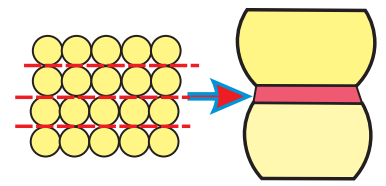

(8)

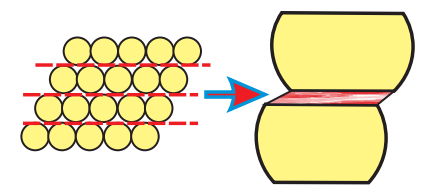

Рис. 22. Схема смещения слоев и изменение контактов зерен при сдвиге (по [Bykov, 1999, 2000]).

(a) - контакт реальных зерен; (б) - равновесное состояние кубической упаковки зерен; (в) - изменение геометрии контакта.

Fig. 22. Scheme of layer shifting and changes in grain contacts due to strike-slip (after [Bykov, 1999, 2000]).

(a) - contact of real grains; (б) - equilibrium state of cubic grain package; $(8)$ - change of the contact geometry.

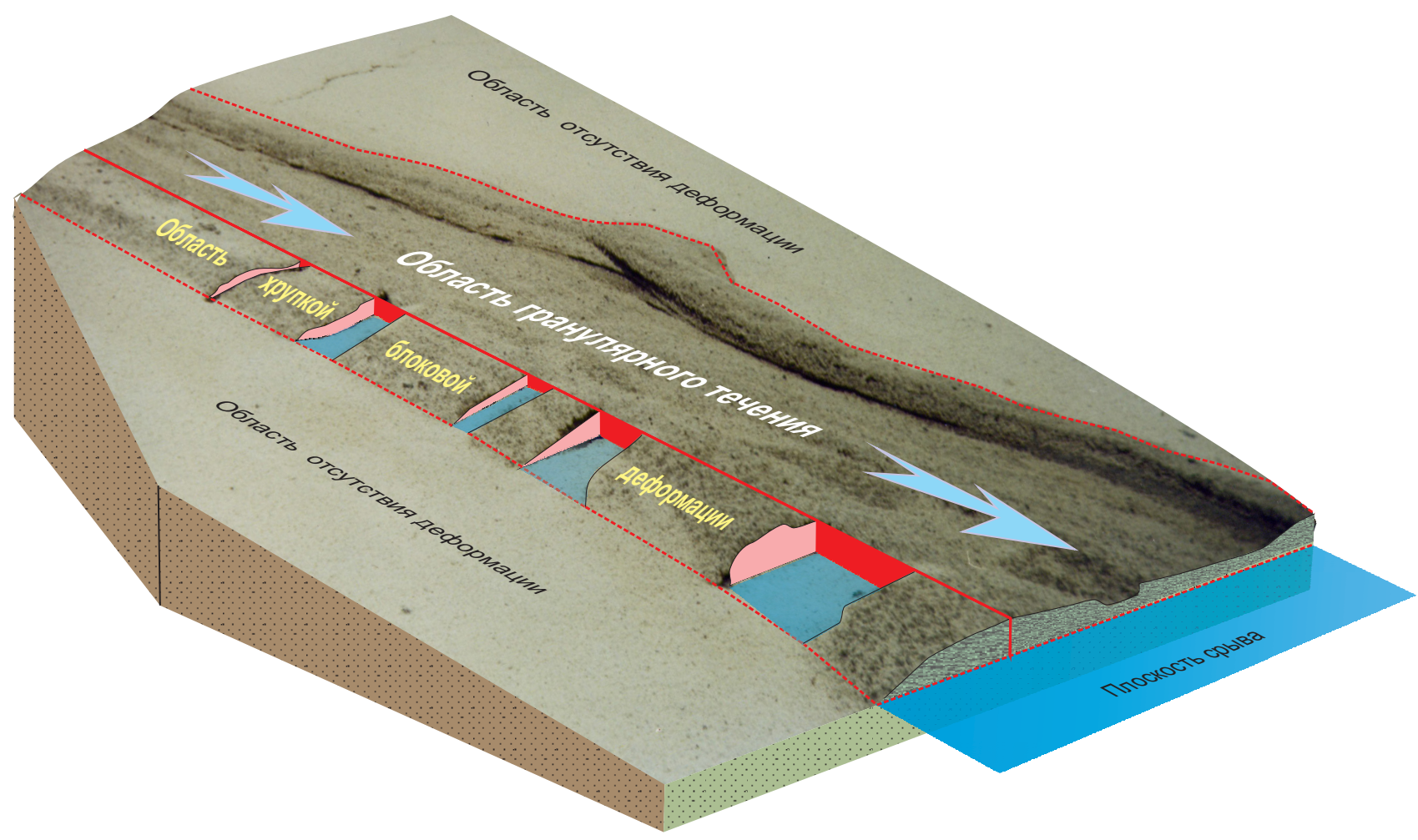

Рис. 23. Различные формы деформации зернового потока. Объяснения в тексте.

Fig. 23. Various forms of deformation within a grain stream (explanations in the text).

скольжения, вдоль которых отдельные слои зерен (блоков) смещаются как единое целое [Sadovsky, 1989].

При этом происходит разупрочнение фрагментированного материала на микроуровне и уменьшение коэффициента трения качения между частицами в макромасштабе. Лабораторное изучение гранулированного потока показало, что неустойчивость скольжения связана с разуплотнением (дилатансией) слоя частиц между границами раздела, и это приводит к ослаблению контакта между блоками [Bykov, 2000].
Эффект дилатансии [Reynolds, 1885] - необратимого увеличения объема материала, в том числе скальных пород [Brace et al.,1966; Mead, 1925], - особенно заметен при сдвиговом деформировании и вязко-катакластическом течении дискретных сред. С дилатансией связаны процессы разупрочнения горных пород и распространения флюидов в земной коре. Дилатансионный эффект, вызываемый процессом дезинтеграции (грануляции), значительно превосходит по величине изменение объема при декомпрессии или контракции. 
При наложении на гидростатическое давление одноосной нагрузки увеличение объема породы может достигать 20 \% [Pospelov, 1972]. Дилатансия способствует уменьшению трения между частицами и облегчает их относительное проскальзывание. Возникающая «пористость» может варьироваться в широких пределах, обычно в интервале 10-25 \% объема, что зависит от формы гранул, их количества, длительности процесса и пр. [Yaeger, Nagel, 1996].

Существует четыре основных механизма деформации гранулированных субстанций [Gol'din, 2002; Kaibyshev, Pshenichnyuk, 1999; Revuzhenko, 2000, 2003]: зернограничное скольжение (сдвиг зерен вдоль их общей границы), поворот зерен (блоков), внутризерновое дислокационное скольжение, диффузионная ползучесть. Основной вклад в деформацию твердых пород в пределах верхней коры, в том числе и в проявление сверхпластичности, вносит зернограничное скольжение и поворот (вращение + сдвиг [Gol'din, 2002]). Переход горных пород в дискретное состояние приводит к понижению их эффективной вязкости, уменьшению сопротивления сдвигу и дилатансии, что вызывает объемную подвижность горных масс и их реидное течение. Крайним морфоструктурным выражением 3D-подвижности горных масс являются протрузии (см. рис. 11, 14, $15,21)$. В неоднородно-дезинтегрированных массивах пород в течение деформационной фазы одновременно могут формироваться ромбоэдры нескольких масштабных (фрактальных) уровней [Gol'din, 2002], что было отмечено выше при сравнении мезо- и макроструктуры гранитоидов.

Деформации в гранулированных средах практически не зависят от реологических свойств фрагментовгранул, а определяются их морфологией и «трением» на контактах. Реологически деформация описывается как пластическое или вязкое течение. При этом силы трения гранулированной среды на бортах потока существенно меньше сил трения в самом потоке, а реологические свойства гранулированной среды могут приближаться к обычной вязкой ньютоновской жидкости [Shvab, Martsenko, 2011]. Инфраструктура природных и модельных объектов до и после деформации обнаруживает разительное сходство (рис. 24).

Для постмагматической дезинтеграции кристаллических пород, например гранитов, характерны овоидные формы, образованные зонами повышенной трещиноватости, обрамляющими блоки менее раздробленных пород (см. рис. 19). Данные экспериментов и наблюдения в горных выработках [Terpigorev, 1958; Oparin, Tanaino, 2011; Oparin et al., 2010; Shemyakin et al., 1986] показали, что возникновение таких структур связано с «зональной дезинтеграцией», при которой в горном массиве возникают структурно-плотностные неоднородности в виде чередующихся относительно ненарушенных зон и зон интенсивно раздробленных пород. Зональная дезинтеграция проявляется при достижении литостатического давления, равного прочности пород на одноосное сжатие или превышающего ее.
Сопряженным с явлением зональной дезинтеграции является эффект формирования «ячеистых структур», которые возникают в результате процесса самоорганизации пространства в неоднородном силовом поле [Kurlenya et al., 1992; Oparin, Tanaino, 2011]. Ячеи состоят из «ядра» с относительно пониженной плотностью породной массы и оболочки, включающей зону аномально высокой плотности. На границах ячей происходит экранирование $\mathrm{P}_{\text {lit }}$ и трансформация нормальных напряжений в касательные, а ядро оказывается в условиях пониженных напряжений и деформаций.

Эти положения согласуются со свойственным дискретным средам способом передачи напряжений через контакты зерен (гранул, блоков), при котором формируется так называемая «сетка напряжений» («стрессовые» или «силовые цепочки»] [Kocharyan, 2016; Behringer et al., 1999; Cambell, 1990; Yaeger, Nagel, 1996] (рис. 25), образованные частицами, нагруженными сильнее, чем основная масса породы [Dorostkar, Carmeliet, 2018; Gao et al., 2019; McBeck et al., 2019].

Объемы внутри ячей этой сетки в меньшей степени испытывают приложенные к гранулированному телу нагрузки, что способствует образованию линзовидно-ромбоэдровидных фрагментов относительно монолитных пород, разделенных интерфейсными зонами с пониженными прочностными и деформационными характеристиками, что способствует локализации и накоплению на них необратимых деформаций [Astafurov et al., 2011; Psakhie et al., 2010, 2011; Frye, Marone, 2002; Gudehus, 2011]. Блоки, ограниченные интерфейсными зонами, находятся вне прямого влияния данного поля напряжений, как бы исключаются из деформационного процесса и сохраняют исходную структуру. (a)

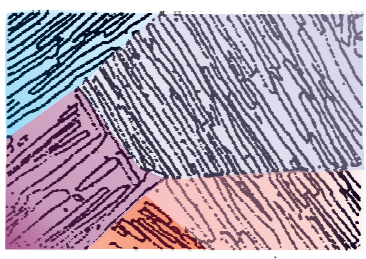

(B)

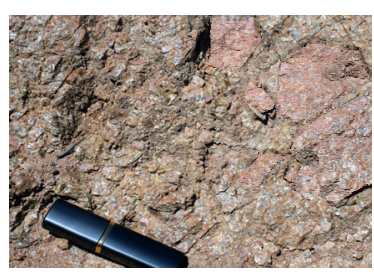

(б)

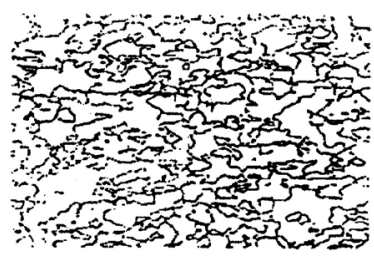

(2)

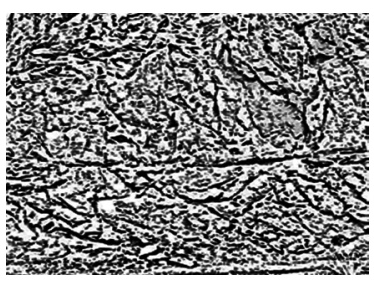

Рис. 24. Преобразование структуры гранулированных сред в результате пластической деформации.

$(a$, б) - микромасштаб [Kaibyshev, Pshenichnyuk, 1999]; (в, г) - в гранитах кристаллической протрузии Танын (мезомасштаб). Видно сходство вновь образованной инфраструктуры.

Fig. 24. Structure transformation of the granular substance due to plastic deformation.

$(a$, б) - microscale [Kaibyshev, Pshenichnyuk, 1999]; $(8,2)$ - in granites of the Tanyn crystalline protrusion (mesoscale). A similarity of the newly formed infrastructure is visible. 
При деформировании стрессовые цепочки испытывают неоднократные циклы нагружения и разрушения. Одновременный разрыв нескольких цепочек приводит к резкому снижению сопротивления сдвигу и к возникновению динамической неустойчивости (рис. 25, а).

В условиях эксперимента при малых нормальных напряжениях и шероховатых поверхностях блоков разрушение цепочек происходит в результате проскальзывания гранул, составляющих цепочку. Линзовидноромбоэдровидная фрагментация горных пород - одна из наиболее ярких морфо- и инфраструктурных форм на всех масштабных уровнях делимости.

Таким образом, дезинтеграция и разрыхление играют существенную роль в формировании структуры и реологии горных пород, и основным фактором этих процессов является фактор тектонический [Leonov et al., 2018]. Процесс механической дезинтеграции и разрыхления проявляется в породах различного состава и в разных геодинамических обстановках, из чего следует, что в основе процесса должен находиться механизм, не зависящий от частных ситуаций, а отражающий фундаментальные законы физики горных пород. Исходя из натурных наблюдений и представлений механики твердого тела логично предположить, что одной из первопричин деформации твердых породных масс, их тектонической дезинтеграции и разрыхления, т.е. создания податливой к силовым воздействиям среды, может быть усталостное разрушение.

Усталостное разрушение (процесс усталостной деструкции) - это один из видов нарушения прочности, который является следствием длительного воздействия повторных или переменных (пульсирующих) нагрузок [Blekhman, 2017; Panasyuk, 1990; Mokhnachev, 1979; Nikolaeva, 2010; Parton, 2020; Ruzhich, 1997; и мн. др.]. Усталостное разрушение - это фундаментальный процесс, свойственный как природным, так и искусственным материалам, и одна из главных причин более $90 \%$ аварийного разрушения машин и инженерных конструкций под действием циклически изменяющихся напряжений, значительно меньших, чем предел прочности или текучести [Golovin, Pushkar, 1980].

Горным породам также свойственно явление усталости, однако это явление в контексте задач структурной геологии и тектоники нашло отражение лишь в немногих работах (например [Adushkin et al., 2009; Коcharyan, Rodionov, 1988; Ruzhich, 1997; Sadovsky et al., 1981]). Основной характеристикой прочности горных пород служит предел прочности $\left(\sigma_{\text {п }}\right)$, или «усталостная (a)
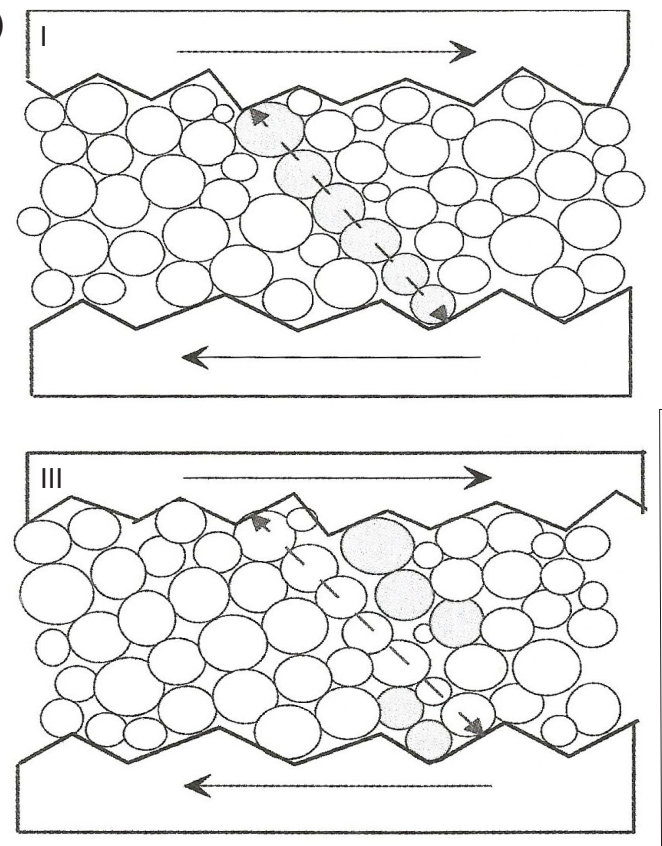

次 1 匀 2

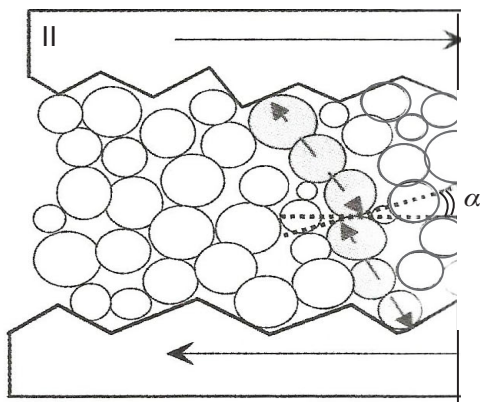

(б)

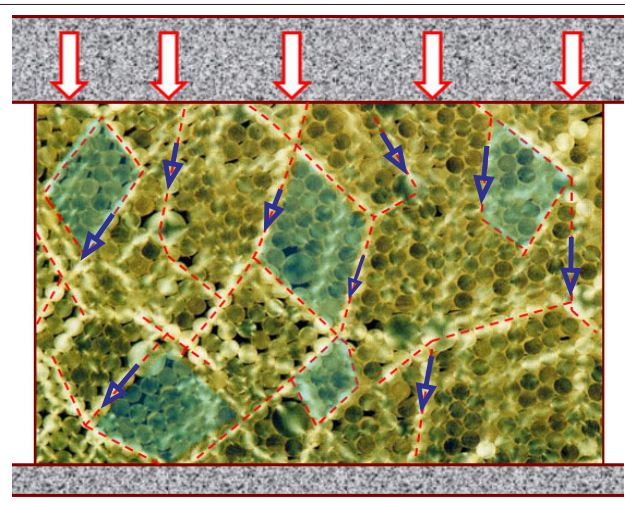

Рис. 25. Сетка напряжений (стрессовые цепочки).

(a) - схема эволюции силовой цепочки при сдвиговом деформировании [Kocharyan, 2016]. Закрашенные ячейки - звенья силовой цепочки; пунктирная линия - ось максимальных напряжений; $\alpha$ - угол рассогласования между плоскостью относительного сдвига частиц и макроскопической плоскостью общего сдвигового перемещения. I, II, III - стадии процесса. (б) - передача напряжений в оптически активных средах при сдвиговом деформировании [Yaeger, Nagel, 1992$] .1$ - линии передачи напряжений; 2 - направление стресса.

Fig. 25. Stress grid (stress chains).

(a) - scheme of the power chain evolution during strike-slip deformation [Kocharyan, 2016]. Painted cells - links of the power chain; dotted line - axis of maximum stress; $\alpha$-angle of discrepancy between the plane of particles relative movement and the macroscopic plane of general strike-slip movement. I, II, III - stages of the process. (б) - stress transmission in optically active materials during strike-slip deformation [Yaeger, Nagel, 1992]. 1 - stress transmission lines; 2 - direction of stress. 
прочность» $\left(\sigma_{y}\right)$. Результаты экспериментального изучения деформационных характеристик различных материалов (бетон, металлы, горные породы) в режиме пульсирующих нагрузок показали существенное снижение значений предела $\sigma_{\text {y }}$ материалов. Установлено, что в горных породах усталостные свойства проявляются более интенсивно, чем в других материалах. Для слабых пород (мергели, глины) величина усталостной прочности составляет 35-60 \%, для крепких (граниты, диабазы, габбро, песчаники, известняки) 22-50 \% от статической прочности. При деформации одноосного сжатия пород (в том числе гранита) в условиях пульсирующего нагружения происходит изменение объема образца $\Delta \mathrm{V} / \mathrm{V}$ (дилатансия), которое прогрессивно увеличивается с увеличением числа циклов нагружения, даже при уменьшении напряжения, при котором дилатансия возникла. Дезинтеграция и дилатансия приводят к разрыхлению пород, которое характеризуется коэффициентом разрыхления $\left(\mathrm{K}_{\mathrm{p}}\right)$ - отношением объема породы после деформации $\left(\mathrm{V}_{2}\right)$ к объему породы до деформации $\left(\mathrm{V}_{1}\right) . \mathrm{K}_{\mathrm{p}}$ всегда $>1$, но применительно к большим массивам горных пород может быть определен лишь на качественном уровне. Эксперименты показали бо́льшую сопротивляемость пород сжимающим циклическим нагрузкам, чем растягивающим. Растягивающие пульсирующие нагрузки, прилагаемые к горным породам (мрамору, граниту, андезиту, песчанику), составляют соответственно 42, 38, 39, 48 \% от предела статической прочности. Изменение частоты нагружений на величину усталостной прочности, повидимому, влияния не оказывает.

Периодические (пульсирующие) силы, приложенные к массиву (или образцу горных пород), вызывают появление соответствующих периодических деформаций. Пульсирующие нагрузки в земной коре постоянны и связаны с различными процессами [Trigger Effects..., 2019]. Среди них: сейсмические события [Guseva et al., 2019; Ruzhich, 1997]; вариации параметров сейсмического шума и тремора земной поверхности, источником которых служат воздействия на земную кору внутренних процессов в земных оболочках [Lyubushin, 2019]; прерывистое фрикционное скольжение литопластин, вызванное нестационарным ротационным фактором [Ovchinnikov, Krasnoshchekov, 2019] или иными причинами; периодическая смена режимов тектонического растяжения/сжатия (транстенсии/транспрессии) [Моrozov et al., 2014]; приливные силы, возникающие в результате гравитационного взаимодействия в системе Земля - Луна - Солнце [Adushkin, Spivak, 2014; Revuzhenko, 2013]; прецессионное движение структурных блоков, установленное при синхронных наклономерных и длиннопериодных сейсмических наблюдениях [Spivak, Kishkina, 2010]. Этот механизм приводит к периодической вибрации и пространственному смещению блоков земной коры, суточные сдвиговые движения которых могут достигать 1-5 мм/сут. Скорость прецессионных движений почти на три порядка превышает скорость вековых движений, что определяет значимость прецессионных движений для преобразования структуры среды в целом и вещества - заполнителя межблокового пространства.

Влияние пульсирующих нагрузок на прочностные и деформационные свойства горных пород проявляются в ускоренном развитии деформации ползучести и в резком снижении прочности за весьма малые промежутки времени по сравнению с долговременными статическими нагрузками при одних и тех же условиях их приложения [Voznesensky et al., 2019]. При циклическом деформировании горных пород обнаружено несовпадение зависимости между усилием и деформацией при нагрузке и разгрузке, что свидетельствует о неупругом характере деформирования [Stefanov, 2002, 2016]. Это явление (гистерезис) показывает, что часть работы внешних сил необратимо поглощается материалом тела. Если уровень квазистатической нагрузки невелик, то петли гистерезиса остаются замкнутыми. Если тело нагружено полем квазистатических напряжений, эффект гистерезиса при воздействии вибраций приводит к возникновению остаточных деформаций, локализованных на структурных неоднородностях. При этом скорость накопления деформации тем выше, чем ближе статическая нагрузка к предельной [Adushkin et al., 2009; Kocharyan et al., 2004]. Этот вывод находит подтверждение в численном моделировании [Lavrikov, Revuzhenko, 2019a, 2019b; Jing, Stephansson, 2007], которое показало, что периодические деформации способны приводить к необратимым изменениям внутренней структуры геосреды и к длительному накоплению упругой энергии, называемой скрытой, собственной, или латентной [Bogomolov et al., 2000; Kosykh V.P., Kosykh P.V, 2017; Kuksenko et al., 2003; Lavrikov, Revuzhenko, 2016; Ponomarev, 2008, 2011; Sibiryakov, Podberezhny, 2006].

Высвобождение накопленной энергии может осуществляться в двух режимах: устойчивом, когда релаксация внутренних напряжений протекает сравнительно медленно и приводит к адекватной (сравнимой с вызвавшим ее внешним воздействием) реакции массива, и неустойчивом (в ряде случаев - катастрофическом). В последнем случае сравнительно малое внешнее воздействие может сыграть роль триггера, развязывающего запасенную энергию, и перестройка внутренней структуры среды происходит путем последовательной смены различных равновесных состояний, сменяющих друг друга в скачкообразном режиме. Длительно проявляющиеся внешние слабые воздействия приводят к накоплению микросдвигов между отдельными фрагментами среды и к росту внутренних напряжений, т.е. к накоплению упругой энергии. Затем, при накоплении достаточной энергии, в среде за сравнительно короткое время происходит макросдвиг, приводящий к перестройке внутренней структуры и новому равновесному состоянию. В частности, показано [Kopeliovich, Kosykh, 2019], что при многократных слабых ударных взаимодействиях изменение деформации происходит немонотонно - возникают отдельные участки роста и падения напряжения; образец периодически запасает, 
а потом высвобождает энергию ударных импульсов, накопленную в процессе эксперимента.

Даже кратковременное вибрационное воздействие в напряженной блочной среде способно инициировать медленный деформационный процесс, вклад которого в интегральную величину накопленной деформации может быть весьма значителен. Если на слабонапряженных контактах превалирует динамическая компонента, то по мере приближения статической нагрузки к пределу прочности амплитуда медленного движения может намного превышать инициирующие динамические перемещения. Такие эффекты наблюдались как в лаборатории [Kocharyan et al., 2004], так и в природе [Glowacka et al., 2002]. Усталостное разрушение горных пород зависит от петрографического и минералогического состава, текстуры и структуры пород, физического состояния, вида напряженного состояния, режима приложения нагрузок и других факторов.

Для циклических нагрузок характерно периодическое нагружение и разгружение пород. Микротрещины, возникшие при нагружении, при разгрузке полностью не закрываются, материал не возвращается к первоначальному состоянию, и эти дефекты при новом нагружении изменяют вторичное поле напряжений. В результате накапливаются необратимые деформации и деформации виброползучести, а процесс разрыхления захватывает все бо́льшие объемы геологического тела. Фиксируется появление на изломе смятых и истертых в порошок кристаллов (в природе - катаклазиты, милониты, тектонокластиты). Кроме того, для различных типов горных пород (габбро, мраморы, песчаники), испытанных в режиме циклического нагружения, установлена независимость предельных деформаций от величины прикладываемых напряжений и числа циклов нагружения. Цикл «нагружение/разгрузка» приводит к увеличению энергетического потенциала деформированного объема, который может запасать до 30 \% энергии, затраченной на его деформирование [Lavrikov, Revuzhenko, 2019a, 2019b]. Все это приводит к знакопеременной реакции массива на внешние воздействия. Отдельные области массива могут сначала аккумулировать энергию внешних воздействий, а затем, при определенных условиях, высвобождать ее, т.е. выступать сначала в роли стоков, а затем - в роли потенциальных источников энергии. После снятия нагрузки деформированный объем может самопроизвольно возрасти (эффект последействия) с возникновением областей разупрочнения, т.е. после снятия нагрузки породный образец совершает работу за счет внутренних ресурсов, приобретенных в процессе деформации. Высвобождение энергии может приводить к спонтанным динамическим скачкам разуплотнения [Revuzhenko, 2003]. Материал, подверженный действию знакопеременной и повторной нагрузки, как показывает опыт, разрушается не только при действии напряжения ниже предела прочности, но часто и ниже предела текучести. При большом числе повторных нагружений и сравнительно низких напряжениях наблюдаются хрупкие разрушения даже у весьма пластичных металлов. Дилатансия не только приводит к увеличению объема горных пород, но и способствует уменьшению трения между частицами и, соответственно, облегчает их относительное проскальзывание. Возникающая «пористость», которая частично или полностью компенсируется минерализацией, может варьироваться в широких пределах, обычно в интервале 10-25 \% объема, что зависит от формы гранул, их количества, длительности процесса, величины деформации и др. В теории разрыхления отмечено также взаимодействие процессов разрыхления материала и пластической деформации.

\section{4. ЗАКЛЮЧЕНИЕ}

Изложенный материал позволяет сделать некоторые выводы относительно особенностей деформации и механизмов формирования инфраструктуры неслоистых геологических тел, сложенных кристаллическими и зернистыми породными комплексами различного состава и возраста и сформированных в разных геодинамических обстановках. В этой статье рассмотрены пространственно ограниченные и относительно автономные объекты, которые обладают своей собственной инфраструктурой и не обнаруживают непосредственной связи с равными по рангу или превосходящими их разломными структурами.

Изученные тела обладают гранулярно-блоковой инфраструктурой - исходной в случае зернистых пород и в значительной степени наведенной вторичной - в случае пород кристаллических. Породные комплексы с гранулярно-блоковой инфраструктурой характеризуются ослаблением или потерей внутренней связности и разрыхлением, что стимулирует проявление объемной подвижности (текучести) горных пород в твердом состоянии, т.е. их реидное поведение, в результате которого формируются своеобразные морфо- и инфраструктурные ансамбли.

Анализ, основанный на полевых структурно-геологических данных и данных физики твердого тела, позволяет заключить, что одним из существенных (не единственных, конечно, но весьма важных) факторов (триггеров) процесса объемной дезинтеграции породных массивов является усталость горных пород - одно из фундаментальных явлений физики твердого тела, а поведение дезинтегрированных горных пород (в том числе особенности деформации и кинематики) подчиняется законам механики гранулированных сред или мезомеханики. Принципиально важно также понимание того, что деформация горных пород может осуществляться при нагрузках, существенно меньших, чем предел их прочности, и захватывать объемы, относительно независимые от внешнего динамического влияния.

Явление объемного разрушения кристаллических горных масс и связанные с этим тектонические следствия были названы Г. Штилле «тектоникой разрыхления» (нем. Lockertektonik; англ. loosening tectonics) [Stille, 1964]. Представлениям Г. Штилле созвучно мнение М.А. Садовского [Sadovsky, 1979, 1989] о блоковости, 
кусковатости горных масс. Новые данные, частично изложенные в статье, дают основание сохранить этот термин за подобным стилем переработки горных масс и считать, что «тектоника разрыхления» - это фундаментальное явление в системе преобразования структуры земной коры. В этом отношении небезынтересно вспомнить и такое явление, как регматическая разломная сеть, которая отражает процесс разрыхления в масштабе верхней оболочки Земли. Исследование имеет и прагматическое значение, поскольку позволяет глубже понять процесс формирования кристаллических протрузий - вместилищ углеводородов в фундаменте многих геоструктур [Leonov et al., 2018]. Искусственно вызванное механическое разрыхление значительно повышает пористость горных пород и нефтеотдачу скважин [Zapivalov, 2014].

\section{5. БЛАГОДАРНОСТИ}

Работа выполнена по теме Госзадания ФГБУН ГИН РАН (описание типов и механизмов деформации) при финансовой поддержке Российского научного фонда (проект № 16-17-10059 - описание постмагматической структуры гранитов, общие вопросы механики и физики процесса структурной дезинтеграции горных пород).

\section{6. ЛИТЕРАТУРА / REFERENCES}

Adushkin V.V., Kocharyan G.G., Novikov V.A., 2016. Study of Fault Slip Modes. Izvestiya. Physics of the Solid Earth 5,1324 (in Russian) [Адушкин В.В., Кочарян Г.Г., Новиков В.А. Исследование режимов движения по разлому // Физика Земли. 2016. № 5. C. 13-24]. https://doi.org/10.7868/ S000233371605001X.

Adushkin V.V., Kocharyan G.G., Pavlov D.V., Vinogradov E.A., Goncharov A.I., Kulikov V.I., Kulyukin A.A., 2009. On the Influence of Seismic Vibrations on the Development of Tectonic Deformations. Reports of the Academy of Sciences 426 (1), 98-100 (in Russian) [Адушкин В.В., Кочарян Г.Г., Павлов Д.В., Виноградов Е.А., Гончаров А.И., Куликов В.И., Кулюкин А.А. О влиянии сейсмических колебаний на развитие тектонических деформаций // Доклады РАН. 2009. T. 426. № 1. C. 98-100].

Adushkin V.V., Spivak A.A., 2014. Physical Fields in Subsurface Geophysics. GEOS, Moscow, 260 p. (in Russian) [Адушкин В.В., Спивак А.А. Физические поля в приповерхностной геофизике. М.: ГЕОС, 2014. 260 с.].

Areshev E.G., Gavrilov V.P., Dong Ch.L., Zhao N., Popov O.K., Pospelov V.V., Shan N.T., Shnip O.A., 1997. Geology and Oil and Gas Potential of the Zonda Shelf Basement. Neft i Gaz, Moscow, 288 p. (in Russian) [Арешев Е.Г., Гаврилов В.П., Донг Ч.Л., Зао Н., Попов О.К., Поспелов В.В., Шан Н.Т., Шнип О.А. Геология и нефтегазоносность фундамента Зондского шельфа. М.: Нефть и газ, 1997. 288 с.].

Astafurov S.V., Shil'ko E.V., Andreev A.V., Psakhie S.G., 2011. Study of the Influence of Nonequilibrium Compression on Dilatancy Processes in a Block Medium Under Conditions of Shear Deformation. Physical Mesomechanics 14 (2), 47-55 (in Russian) [Астафуров С.В., Шилько Е.В., Андреев А.В., Псахье С.Г. Исследование влияния неравновесности сжатия на дилатансионные процессы в блочной среде в условиях сдвигового деформирования // Физическая мезомеханика. 2011. Т. 14. № 2. С. 47-55].

Azhgirey G.D., 1966. Structural Geology. Moscow State University, Moscow, 348 p. (in Russian) [Ажгирей Г.Д. Структурная геология. М.: МГУ, 1966. 348 с.].

Behringer R.P., Howell D., Kondic L., Tennakoon S., Veje Ch., 1999. Predictability and Granular Materials. Physica D: Nonlinear Phenomena 133 (1-4), 1-17. https://doi.org/ 10.1016/S0167-2789(99)00094-9.

Beroush R.A., 1991. Basement. In: Structural Geology and Plate Tectonics. Vol. 3. Mir, Moscow, p. 265-269 (in Russian) [Бероуш Р.А. Фундамент // Структурная геология и тектоника плит. М.: Мир, 1991. Т. 3. С. 265-269].

Blekhman I.I., 1994. Vibration Mechanics. Fizmatlit, Moscow, 400 p. (in Russian) [Блехман И.И. Вибрационная механика. М.: Физматлит, 1994. 400 с.].

Blekhman I.I., 2017. What Can Vibration Do? About Vibration Mechanics and Vibration Technology. LENAND, Moscow, 216 p. (in Russian) [Блехман И.И. Что может вибрация? О вибрационной механике и вибрационной технике. М.: ЛЕНАНД, 2017. 216 с.].

Bobryakov A.P., Kosykh V.P., Lubyagin A.V., 2010. Instability of Plastic Flow of Loose Materials under Static Loading and Weak Shaking. In: Trigger Effects in Geosystems. Materials of the All-Russia Seminar-Conference (22-24 June 2010, Moscow). GEOS, Moscow, 175-183 (in Russian) [Бобряков А.П., Косых В.П., Лубягин А.В. Неустойчивость пластического течения сыпучих сред при статических нагрузках и слабых сотрясениях // Триггерные эффекты в геосистемах: Материалы Всероссийского семинарасовещания (22-24 июня 2010 г., Москва). М.: ГЕОС, 2010. C. 175-183].

Bobryakov A.P., Kosykh V.P., Revuzhenko A.F., 2015. Triggering of Elastic Energy Discharge in Strained Geomedium. FTPRPI (Physical and Technical Problems of Mineral Exploration) 1, 14-22 (in Russian) [Бобряков А.П., Косых В.П., Ревуженко А.Ф. Триггерное инициирование разрядки упругой энергии в напряженной геосреде // ФТПРПИ. 2015. № 1. C. 14-22].

Bogdanov A.N., Skvortsov A.T., 1992. Nonlinear Shear Waves in Granular Medium. Acoustics Journal 38 (3), 408412 (in Russian) [Богданов А.Н., Скворцов А.Т. Нелинейные сдвиговые волны в зернистой среде // Акустический журнал. 1992. Т. 38. Вып. 3. С. 408-412].

Bogomolov L.M., Trapeznikov Yu.A., Manzhikov B.Ts., 2000. Influence of Weak Vibrations on Deformation of Rocks at Constant Loading. Volcanology and Seismology 2, 1-4 (in Russian) [Богомолов Л.М., Трапезников Ю.А., Манжиков Б.Ц. Влияние слабых вибраций на деформирование горных пород при постоянной нагрузке // Вулканология и сейсмология. 2000. № 2. С. 1-4].

Brace W.F., Pauling B.W., Scholz C., 1966. Dilatancy in the Fracture of Crystalline Rocks. Journal of Geophysical Research 71 (16), 3939-3953. https://doi.org/10.1029/ JZ071i016p03939.

Bradschaw J., Renouf J.T., Taylor R.T., 1967. The Development of Brioverian Structures and Brioverian / Paleozoic 
Relationships in West Finist'ere (France). Geologische Rundschau 56 (2), 567-596. https://doi.org/10.1007/BF018 48744.

Budkov A.M., Ostapchuk F.F., 2013. Numerical Modeling of Discontinuous Sliding. In: Dynamic Processes in Geospheres. Collection of Scientific Papers of the Institute of Mining RAS. Iss. 4. GEOS, Moscow, p. 103-110 (in Russian) [Будков A.M., Остапчук Ф.Ф. Численное моделирование процесса прерывистого скольжения // Динамические процессы в геосферах: Сборник научных трудов ИГД РАН. М.: ГЕОС, 2013. Вып. 4. С.103-110].

Bykov V.G., 1999. Isolated Shear Zones in Granular Medium. Acoustics Journal 45 (2), 169-173 (in Russian) [Быков В.Г. Уединенные сдвиговые зоны в зернистой среде // Акустический журнал. 1999. Т. 45. № 2. С. 169-173].

Bykov V.G., 2000. Nonlinear Wave Processes in Geological Medium. Dalnauka, Vladivostok, 190 p. (in Russian) [Быков В.Г. Нелинейные волновые процессы в геологических средах. Владивосток: Дальнаука, 2000. 190 с.].

Cambell C.S., 1990. Rapid Granular Flows. Annual Review of Fluid Mechanics 22, 57-92. https://doi.org/10.11 46/annurev.fl.22.010190.000421.

Carey S.W., 1954. The Rheid Concept in Geotectonics. Journal of the Geological Society of Australia 1 (1-2), 67117. https://doi.org/10.1080/14400955308527848.

Dorostkar O., Carmeliet J., 2018. Potential Energy as Metric for Understanding Stick-Slip Dynamics in Sheared Granular Fault Gouge: A Coupled CFD-DEM Study. Rock Mechanics and Rock Engineering 51, 3281-3294. https://doi.org/10. 1007/s00603-018-1457-6.

Drake T.G., 1990. Structural Features in Granular Flow. Journal of Geophysical Research: Solid Earth 95 (B6), 86818696. https://doi.org/10.1029/JB095iB06p08681.

Ermikov V.D., 1994. Mesozoic Precursors of the Cenozoic Rift Structures of Central Asia. Bulletin des Centres de Recherches Exploration 18, 123-134.

Eshelby J.D., 1963. Continuous Dislocation Theory. Foreign Literature, Moscow, 274 p. (in Russian) [Эшелби Дж. Континуальная теория дислокаций. М.: Иностранная литература, 1963. 274 с.].

Foose R., 1976. Vertical Tectonic Movements and Gravity in the Big Horn Depression and in the Surrounding Ridges of the Middle Rocky Mountains. In: Gravity and Tectonics. Mir, Moscow, p. 434-445 (in Russian) [Фуз Р. Вертикальные тектонические движения и сила тяжести во впадине Биг-Хорн и в окружающих хребтах Средних скалистых гор // Сила тяжести и тектоника. М.: Мир, 1976. C. 434-445].

Frye K.M., Marone C., 2002. The Effect of Particle Dimensionality on Granular Friction in Laboratory Shear Zones. Geophysical Research Letters 29 (19), 1916-1919. https:// doi.org/10.1029/2002GL015709.

Gao K., Guyer R., Rougier E., Ren C.X., Johnson P.A., 2019. From Stress Chains to Acoustic Emission. Physical Review Letters 123, 048003. https://doi.org/10.1103/PhysRevLett. 123.048003.

Garagash I.A., 1982. Formation of Cellular Structures in Elastoplastic Medium with Internal Friction and Dilatancy.
Reports of the USSR Academy of Sciences 266 (1), 59-63 (in Russian) [Гарагаш И.А. Образование ячеистых структур в упругопластической среде с внутренним трением и дилатансией // Доклады АН СССР. 1982. Т. 266. № 1. C. 59-63].

Garagash I.A., 2006. Conditions for Formation of Regular Systems of Shear and Compaction Bands. Geology and Geophysics 47 (5), 657-668 (in Russian) [Гарагаш И.А. Условия формирования регулярных систем полос сдвига и компакции // Геология и геофизика. 2006. Т. 47. № 5. C. 657-668].

Garagash I.A., Nikolaevsky V.N., 1989. Non-Associated Laws of Flow and Localization of Plastic Deformation. Achievements in Mechanics 12 (1), 131-183 (in Russian) [Гарагаш И.А., Николаевский В.Н. Неассоциированные законы течения и локализация пластической деформации //Успехи механики. 1989. Т. 12. № 1. С. 131-183].

Garagash I.A., Nikolaevsky V.N., 1994. Conditions for Limiting Equilibrium of Fragmented Rock Masses at Macroand Microscales. Reports of the USSR Academy of Sciences 338 (5), 675-679 (in Russian) [Гарагаш И.А., Николаевский В.Н. Условия предельного равновесия фрагментированных горных масс в макро- и микромасштабе. Доклады АН СССР. 1994. Т. 338. № 5. С. 675-679].

Gatinsky Yu.G., Prokhorova T.V., Rundquist D.V., 2018. The 102-103 ${ }^{\circ}$ E Geodivider in the Modern Lithosphere Structure of Central Asia. Geodynamics \& Tectonophysics. 9 (3), 989-1006. https://doi.org/10.5800/GT-2018-9-3-0380.

Glowacka E., Nava A.F., Cossio D.D., Wong V., Farfan F., 2002. Fault Slip, Seismicity, and Deformation in the Mexicali Valley, Baja California, Mexico, after the M 7.1 Hector Mine Earthquake. Bulletin of the Seismological Society of America 92 (4), 1290-1299. https://doi.org/10.1785/0120000911.

Glushanin L.V., Sharov N.V., Shchiptsov V.V. (Eds), 2011. Onega Paleoproterozoic Structure (Geology, Tectonics, Deep structure and Minerageny). KSC RAS, Petrozavodsk, 431 p. (in Russian) [Онежская палеопротерозойская структура (геология, тектоника, глубинное строение и минерагения) / Ред. Л.В. Глушанин, Н.В. Шаров, В.В. Щипцов. Петрозаводск: КНЦ РАН, 2011. 431 с.].

Golovin S.A., Pushkar A.V., 1980. Microplasticity and Fatigue of Metals. Metallurgy, Moscow, 240 p. (in Russian) [Головин С.А., Пушкар А.В. Микропластичность и усталость металлов. М.: Металлургия, 1980. 240 с.].

Gol'din S.V., 2002. Lithosphere Destruction and Physical Mesomechanics. Physical Mesomechanics 5 (5), 5-22 (in Russian) [Гольдин C.В. Деструкция литосферы и физическая мезомеханика // Физическая мезомеханика. 2002. T. 5. № 5. C. 5-22].

Gol'din S.V., 2005. Macro- and Mesostructures in Earthquake Focal Areas. Physical Mesomechanics 8 (1), 5-14 (in Russian) [Гольдин C.B. Макро- и мезоструктуры очаговой области землетрясения // Физическая мезомеханика. 2005. Т. 8. № 1. С. 5-14].

Gudehus G., 2011. Physical Soil Mechanics. Springer-Verlag, Berlin, 835 p. https://doi.org/10.1007/978-3-540-36354-5.

Guseva T.V., Krupennikova I.S., Mokrova A.N., Rozenberg N.K., 2019. Interaction of Deformation Field and Local 
Seismicity in North Caucasus. In: Trigger Effects in Geosystems. Abstracts of the 5th International Conference (4-7 June 2019, Moscow). Institute of Geosphere Dynamics, Moscow, p. 57-58 (in Russian) [Гусева Т.В., Крупенникова И.С., Мокрова А.Н., Розенберг Н.К. Взаимодействие деформационного поля и местной сейсмичности на Северном Кавказе // Триггерные эффекты в геосистемах: Тезисы докладов V Международной конференции (4-7 июня 2019, Москва). М.: ИДГ РАН, 2019. С. 57-58].

Hellan K., 1988. Introduction to Fracture Mechanics. Mir, Moscow, 364 p. (in Russian) [Хеллан К. Введение в механику разрушения. М.: Мир, 1988. 364 с.].

Jing L., Stephansson O., 2007. Fundamental of Discrete Elements Methods for Rock Engineering. Elseiver 85, 545 p. https://doi.org/10.1016/j.ijrmms.2008.04.003.

Jullien R., 1992. La Ségrégation Chez Les Grains De Sable. Recherche 23 (247), 1198-1199.

Kaibyshev O.A., 2000. Scientific Foundations, Achievements and Prospects of Superplastic Deformation. GILEM, Ufa, 149 p. (in Russian) [Кайбышев O.A. Научные основы, достижения и перспективы сверхпластической деформации. Уфа: ГИЛЕМ, 2000. 149 с.].

Kaibyshev O.A., Pshenichnyuk A.I., 1999. Structural Superplasticity: from Deformation Mechanism to Major Ratios. Bulletin of the Russian Academy of Sciences. Rigid Body Mechanics 5, 148-164 (in Russian) [Кайбышев 0.А., Пшеничнюк А.И. Структурная сверхпластичность: от механизма деформации к определяющим соотношениям // Известия РАН: Механика твердого тела. 1999. № 5. C. 148-164].

King L., 1967. Earth Morphology. Progress, Moscow, 555 р. (in Russian) [Кинг Л. Морфология Земли. М.: Прогресс, 1967. 559 с.]. https://search.rsl.ru/ru/record/010 06301580.

Kocharyan G.G., 2016. Fault Geomechanics. GEOS, Moscow, 442 p. (in Russian) [Кочарян Г.Г. Геомеханика разломов. M.: ГEOC, 2016. 424 c.].

Kocharyan G.G., Kostyuchenko V.N., Pavlov D.V., 2004. Initiation of Deformation Processes in the Earth's Crust by Small Perturbations. Physical Mesomechanics 7 (1), 5-22 (in Russian) [Кочарян Г.Г., Костюченко В.Н., Павлов Д.В. Инициирование деформационных процессов в земной коре слабыми возмущениями // Физическая мезомеханика, 2004. Т. 7. № 1. С. 5-22].

Kocharyan G.G., Rodionov V.N., 1988. On the Nature of Tectonic Forces. Bulletin of the USSR Academy of Sciences 302 (2), 304-305 (in Russian) [Кочарян Г.Г., Родионов В.Н. О природе тектонических сил // Доклады АН СССР. 1988. T. 302. № 2. C. 304-305].

Kocharyan G.G., Spivak A.A., 2003. Dynamics of Deformation of Block Massifs of Rocks. Akademkniga, Moscow, 424 p. (in Russian) [Кочарян Г.Г., Спивак А.А. Динамика деформирования блочных массивов горных пород. М.: Академкнига, 2003. 424 с.].

Kolodyazhny S.Yu., 2006. Structural and Kinematic Evolution of the South-Eastern Part of the Baltic Shield in the Paleoproterozoic. GEOS, Moscow, 332 p. (in Russian) [Koлодяжный С.Ю. Структурно-кинематическая эволюция юго-восточной части Балтийского щита в палеопротерозое. М.: ГЕОС, 2006. 332 с.].

Kolodyazhny S.Yu., Zykov D.S., Leonov M.G., Orlov S.Yu., 2000. Features of the Evolution of Dome-Shear Structures in the Northwestern Lake Onega Region (Karelian massif). Russian Journal of Earth Sciences 2 (2), 11-27 (in Russian) [Колодяжный С.Ю., Зыков Д.С., Леонов М.Г., Орлов С.Ю. Особенности эволюции купольно-сдвиговых структур Северо-Западного Прионежья (Карельский массив) // Российский журнал наук о Земле. 2000. Том 2. № 2. C. 11-27].

Kopeliovich A.V., Kosykh V.P., 2019. Influence of Multiple Weak Shock Interactions on the Evolution of Stresses and Deformation of Geomaterials. In: Trigger Effects in Geosystems. Abstracts of the 5th International Conference (4-7 June 2019, Moscow). Institute of Geosphere Dynamics, Moscow, p. 103 (in Russian) [Копелиович А.В., Косых В.П. Влияние многократных слабых ударных взаимодействий на эволюцию напряжений и деформаций геоматериалов // Триггерные эффекты в геосистемах: Тезисы докладов V Международной конференции (4-7 июня 2019 г., Москва). М.: ИДГ РАН, 2019. С. 103].

Kopeliovich A.V., Simanovich I.M., 1963. Differential Slip Structures in Quartzite-Sandstones of the Iotnian Strata of the Lake Onega Region. Bulletin of the USSR Academy of Sciences 151 (3), 675-678 (in Russian) [Копелиович А.В., Симанович И.М. Структуры дифференциального скольжения в кварцитопесчаниках иотнийских толщ Прионежья // Доклады АН СССР. 1963. Т. 151. № 3. C. 675-678].

Kosykh V.P., 2008. Manifestation of the Savard-Masson Effect in Bulk Materials. Physical and Technical Problems of Mining 6, 13-18 (in Russian) [Косых В.П. Проявление эффекта Савара-Массона в сыпучих материалах // Физико-технические проблемы разработки полезных ископаемых. 2008. № 6. С. 13-18].

Kosykh V.P., 2015. Experimental Study of Stress Changes in Granular Media under Small Shocks. In: Fundamental and Applied Problems of Mining Sciences 2 (2), 19-23 (in Russian) [Косых В.П. Экспериментальное исследование изменения напряжений в сыпучих средах при малыхударах // Фундаментальные и прикладные вопросы горных наук. 2015. Т. 2. № 2. С. 19-23].

Kosykh V.P., Kosykh P.V., 2017. On Stress Fluctuations in Geomaterials during Long-Term Weak Dynamic Impacts. In: Trigger Effects in Geosystems. Abstracts of the 4th AllRussia Conference with international participation (6-9 June 2017). GEOS, Moscow, p. 176-182 (in Russian) [Koсых В.П., Косых П.В. О флуктуациях напряжений в геоматериалах в процессе длительных слабых динамических воздействий // Триггерные эффекты в геосистемах: Материалы IV Всероссийской конференции с международным участием (6-9 июня 2017 г.). М.: ГЕОС, 2017. С. 176-182].

Kratts K.O., 1963. Geology of Karelides of Karelia. Publishing House of the USSR Academy of Sciences, MoscowLeningrad, 230 p. (in Russian) [Кратц К.О. Геология карелид Карелии. М.-Л.: Изд-во АН СССР, 1963. 230 с.]. 
Kuksenko V.S., Manzhikov B.Ts., Tilegenov K., Shatemirov Zh.K., Emilbekov B.E., 2003. Trigger Effect of Weak Vibrations in Solids (Rocks). Solid State Physics 45 (12), 2182-2186 (in Russian) [Куксенко В.С., Манжиков Б.Ц., Тилегенов К., Шатемиров Ж.К., Эмильбеков Б.Э. Триггерный эффект слабых вибраций в твердых телах (горных породах) // Физика твердого тела. 2003. Т. 45. Вып. 12. С. 2182-2186].

Kurlenya M.V., Oparin V.N., Matasova G.G., Morozov P.F., Tapsiev A.P., Semenov A.V., 1992. The Effect of Self-Organization of Artificial Massifs with the Formation of Cellular Structures in the Form of a Passive Core and an Active Supporting Shell. Bulletin of the USSR Academy of Sciences 323 (6), 1072-107 (in Russian) [Курленя М.В., Опарин В.Н., Матасова Г.Г., Морозов П.Ф., Тапсиев А.П., Семенов А.В. Эффект самоорганизации искусственных массивов с образованием ячеистых структур в виде пассивного ядра и активной несущей оболочки // Доклады АН СССР. 1992. T. 323. № 6. C. 1072-1077].

Kuzmin Yu.O., 2014. Recent Geodynamics of Fault Zones: Faulting in Real Time Scale. Geodynamics \& Tectonophysics 5 (2), 401-443 (in Russian) [Кузьмин Ю.О. Современная геодинамика разломных зон: разломообразование в реальном масштабе времени // Геодинамика и тектонофизика. 2014. T. 5. № 2. С. 401-443. https://doi.org/10. 5800/GT-2014-5-2-0135.

Lavrikov S.V., Mikenina O.A., Revuzhenko A.F., Shemyakin E.I., 2008. The Concept of Non-archimedean Multiscale Medium and Structured Plastic Medium Models. Physical Mesomechanics 11 (3), 45-60 (in Russian) [Лавриков С.В., Микенина О.А., Ревуженко А.Ф., Шемякин Е.И. Концепция неархимедового многомасштабного пространства и модели пластических сред со структурой // Физическая мезомеханика. 2008. Т. 11. № 3. С. 45-60].

Lavrikov S.V., Revuzhenko A.F., 1994. On the Model of Deformation of Pillars Taking into Account the Effects of Energy Accumulation and Softening of the Material. Physical and Technical Problems of Mining 6, 12-23 (in Russian) [Лавриков С.В., Ревуженко А.Ф. О модели деформирования целиков с учетом эффектов аккумулирования энергии и разупрочнения материала // Физико-технические проблемы разработки полезных ископаемых. 1994. № 6. C. 12-23].

Lavrikov S.V., Revuzhenko A.F., 2015. DEM Code-Based Modeling of Energy Accumulation and Release in Structurally Heterogeneous Rock Masses. AIP Conference Proceedings 1683, 020121. https://doi.org/10.1063/1.4932811.

Lavrikov S.V., Revuzhenko A.F., 2016. Numerical Modeling of the Process of Accumulation and Release of Elastic Energy in Structurally Heterogeneous Geomaterials. Physical and Technical Problems of Mining 4, 22-28 (in Russian) [Лавриков С.В., Ревуженко А.Ф. Численное моделирование процесса накопления и высвобождения упругой энергии в структурно-неоднородных геоматериалах // Физико-технические проблемы разработки полезных ископаемых. 2016. № 4. С. 22-28].

Lavrikov S.V., Revuzhenko A.F., 2017. Modeling of Deformation Processes of Self-Stressed Rock Samples. Physical and Technical Problems of Mining 1, 15-24 (in Russian) [Лавриков С.В., Ревуженко А.Ф. Моделирование процессов деформирования самонапряженных образцов горных пород // Физико-технические проблемы разработки полезных ископаемых. 2017. № 1. С. 15-24].

Lavrikov S.V., Revuzhenko A.F., 2019a. Modeling the Process of Accumulation and Release of Energy in the Geomedium under Tidal Forces. In: Trigger Effects in Geosystems. Abstracts of the 5th International Conference (4-7 June 2019, Moscow). Institute of Geosphere Dynamics (IDG), Moscow, p. 111-112 (in Russian) [Лавриков С.В., Ревуженко А.Ф. Моделирование процесса аккумулирования и высвобождения энергии в геосреде под действием приливных сил // Триггерные эффекты в геосистемах: Тезисы докладов V-й Международной Конференции (4-7 июня 2019, Москва). М.: ИДГ РАН, 2019. С. 111-112].

Lavrikov S.V., Revuzhenko A.F., 2019b. Mathematical Modeling of Deformation of Self-Stress Rock Mass Surrounding a Tunnel. In: W. Wu (Ed.), Desiderata Geotechnica Springer Series in Geomechanics and Geoengineering, 79-85. https:// doi.org/10.1007/978-3-030-14987-1_9.

Lavrushin Yu.A., Chistyakova I.A. (Eds), 2001. Problems of Stratigraphy of the Quaternary Sediments and Paleogeography of the Yaroslavl Volga Region. GEOS, Moscow, 158 p. (in Russian) [Проблемы стратиграфии четвертичных отложений и палеогеографии Ярославского Поволжья / Ред. Ю.А. Лаврушкин, И.А. Чистякова. М.: ГЕОС, 2001. 158 c.].

Lavrushin Yu.A., Chugunny Yu.G., 1982. Kanev Glacial Dislocations. Nauka, Moscow, 102 p. (in Russian) [Лаврушин Ю.А., Чугунный Ю.Г. Каневские гляциодислокации. М.: Наука, 1982. 102 с.].

Leonov M.G., 2008. Tectonics of Consolidated Crust. Proceedings of GIN RAS. Iss. 575. Nauka, Moscow, 457 p. (in Russian] [Леонов М.Г. Тектоника консолидированной коры // Труды ГИН РАН. М.: Наука, 2008. Вып. 575. 457 с.].

Leonov M.G., Kolodyazhnyy S.Yu., Zykov D.S., Lishnevsky E.N., Somin M.L., 2001. Essays on the Post-Archean Geodynamics of the Karelian Massif. Proceedings of GIN RAS. Iss. 536. GEOS, Moscow, 120 p. (in Russian) [Лeoнов М.Г., Колодяжный С.Ю., Зыков Д.С., Лишневский Э.Н., Сомин М.Л. Очерки постархейской геодинамики Карельского массива // Труды ГИН РАН. М.: ГЕОС, 2001. Вып. 536. 120 с.].

Leonov M.G., Przhiyalgovsky E.S., Lavrushina E.V., 2018. Granites. Postmagmatic Tectonics and Hydrocarbon Potential. Proceedings of GIN RAS. Iss. 619. GEOS, Moscow, 332 p. (in Russian) [Леонов М.Г., Пржиялговский Е.C., Лаврушина Е.В. Граниты. Постмагматическая тектоника и углеводородный потенциал // Труды ГИН РАН. М.: ГЕОС, 2018. Вып. 619. 332 с.].

Lukashov A.D., 1974. The Main Features of Neotectonics in Karelia. In: Latest and Modern Crustal Movements in the Eastern Part of the Baltic Shield. Institute of Geology, Karelia Branch of the USSR Academy of Sciences, Petrozavodsk, p. 5-15 (in Russian) [Лукашов А.Д. Основные черты неотектоники Карелии // Новейшие и современные движения земной коры восточной части Балтийского 
щита. Петрозаводск, Институт геологии Карельского Филиала АН СССР. 1974. С. 5-15].

Lukyanov A.V., 1991. Plastic Deformation and Tectonic Flow in the Lithosphere. Nauka, Moscow, 144 p. (in Russian) [Лукьянов А.В. Пластические деформации и тектоническое течение в литосфере. М.: Наука, 1991. 144 с.].

Lyubushin A.A., 2019. Global Connections between the Earth's Own Noises: Tremor of the Earth's Surface, Seismic Noise, and Irregular Rotation of the Planet. In: Trigger Effects in Geosystems. Abstracts of the 5th International Conference (4-7 June 2019, Moscow). Institute of Geosphere Dynamics (IDG), Moscow, p. 119-120 (in Russian) [Любушин А.А. Глобальные связи между собственными шумами Земли: тремор земной поверхности, сейсмические шумы, нерегулярность вращения планеты // Триггерные эффекты в геосистемах. Тезисы докладов V Международной конференции (4-7 июня 2019, Москва). М.: ИДГ РАН, 2019. С. 119-120].

McBeck J., Mair K., Renard F., 2019. How Porosity Controls Macroscopic Failure via Propagating Fractures and Percolating Force Chains in Porous Granular Rocks. Journal of Geophysical Research: Solid Earth 124 (9), 9920-9939. https://doi.org/10.1029/2019JB017825.

Mead W. J., 1925. The Geologic Role of Dilatancy. Journal of Geology 33 (7), 685-698. https://doi.org/10.1086/623241.

Mehta A. (Ed.), 1994. Granular Matter: An Interdisciplinary Approach. Springer-Verlag, New York, 306 p. https:// doi.org/10.1007/978-1-4612-4290-1.

Miller Yu.V., 1997. The Most Important Structural Paragenesis of Crystalline Complexes. In: Materials of the Meeting. GEOS, Moscow, p. 110-112 (in Russian) [Миллер Ю.В. Важнейшие структурные парагенезы кристаллических комплексов // Материалы совещания. М.: ГЕОС, 1997. C. 110-112].

Mokhnachev M.P., 1979. Rock Fatigue. Nauka, Moscow, 152 p. (in Russian) [Мохначев М.П. Усталость горных пород. М.: Наука, 1979. 152 с.].

Morozov Yu.A., Leonov M.G., Alekseev D.V., 2014. PullApart Formation Mechanism of Cenozoic Basins in the Tien Shan and Their Transpressional Evolution: Structural and Experimental Evidence. Geotectonics 1, 29-61 (in Russian) [Морозов Ю.А., Леонов М.Г., Алексеев Д.В. Пулл-апартовый механизм формирования кайнозойских впадин Тянь-Шаня и их транспрессивная эволюция: структурные и экспериментальные свидетельства // Геотектоника. 2014. № 1. С. 29-61]. https://doi.org/10.7868/S00 $16853 X 14010056$.

Mukhamediev S.A., 2016. On Discrete Structure of Geologic Medium and Continual Approach to Modeling Its Movements. Geodynamics \& Tectonophysics 7 (3), 347-381 (in Russian) [Мухамедиев Ш.А. О дискретном строении геосреды и континуальном подходе к моделированию ее движения // Геодинамика и тектонофизика. 2016. Т. 7. № 3. C. 347-381]. https://doi.org/10.5800/GT-2016-7-3-0213.

Nikolaeva E.A., 2010. Fracture Mechanics Foundations. Publishing House of Perm State Technical University, Perm, 103 р. (in Russian) [Николаева Е.А. Основы механики разрушения. Пермь: Изд-во ПГТУ, 2010. 103 с.].
Nicolas A., 1992. Principles of Rock Deformation. Mir Elf Aquiten, Moscow, 166 p. (in Russian) [Николя А. Основы деформации горных пород. М.: Мир «Эльф Акитен», 1992. 166 c.].

Oparin V.N., Tanaino A.S., 2011. Canonical Scale to Represent Hierarchies in Science on Rocks. Nauka, Novosibirsk, 258 p. (in Russian) [Опарин В.Н., Танайно А.С. Каноническая шкала иерархических представлений в горном породоведении. Новосибирск: Наука, 2011. 258 с.].

Oparin V.P., Simonov B.F., Yushkin V.F., Vostrikov V.I., Pogarsky Yu.V., Nazarov L.A., 2010. Geomechanical and Technical Principles for Enhanced Oil Recovery and Vibration Wave Technologies. Nauka, Novosibirsk, 404 p. (in Russian) [Опарин В.П., Симонов Б.Ф., Юшкин В.Ф., Востриков В.И., Погарский Ю.В., Назаров Л.А. Геомеханические и технические основы увеличения нефтеотдачи пластов в виброволновых технологиях. Новосибирск: Наука, 2010. 404 с.].

Ovchinnikov V.M., Krasnoshchekov D.I., 2019. Rotation Factor: Dynamics and Interaction of the Earth's Core and Mantle. In: Trigger Effects in Geosystems. Abstracts of the 5th International Conference (4-7 June 2019, Moscow). Institute of Geosphere Dynamics, Moscow, p. 151 (in Russian) [Овчинников В.М., Краснощеков Д.И. Ротационный фактор: динамика и взаимодействие ядра и мантии Земли // Триггерные эффекты в геосистемах: Тезисы докладов V Международной Конференции (4-7 июня 2019, Москва). М.: ИДГ РАН, 2019. С. 151].

Panasyuk V.V. (Ed.), 1990. Fracture Mechanics and Material Strength. Guidebook. Fatigue and Cyclic Fracture Resistance of Construction Materials. Vol. 4. Naukova Dumka, Kiev, 680 р. (in Russian) [Механика разрушения и прочность материалов: Справ. пособие. Усталость и циклическая трещиностойкость конструкционных материалов / Ред. В.В. Панасюк. Киев: Наукова думка, 1990. Т. 4. 680 с.].

Parton V.Z., 2020. Fracture Mechanics. From Theory to Practice. LKI Publishing House, Moscow. 240 p. (in Russian) [Партон В.3. Механика разрушения. От теории к практике. М.: Изд-во ЛКИ, 2020. 240 с.

Patalakha E.I., 1971. On Differential Mobility of Jointly Deformed Heterogeneous Geological Bodies, Its Causes and Effects. Viscosity Inversion. Geotectonics 4, 15-20 (in Russian) [Паталаха Е.И. О дифференциальной подвижности совместно деформируемых разнородных геологических тел, ее причинах и следствиях. Вязкостная инверсия / / Геотектоника. 1971. № 4. С. 15-20].

Polyakov A.S., 2001. Granular Media and Sedimentation. In: General and Regional Geology, Geology of Seas and Oceans, and Geological Mapping. Geoinformmark, Moscow, p. 5658 (in Russian) [Поляков А.С. Гранулированные среды и седиментогенез // Общая и региональная геология, геология морей и океанов, геологическое картирование. М.: Геоинформмарк, 2001. С. 56-58].

Ponomarev V.S., 2008. Energy Saturation of Geological Environment. Proceedings of GIN RAS. Iss. 582. Nauka, Moscow, p. 1-379 (in Russian) [Пономарев В.С. Энергонасыщенность геологической среды // Труды ГИН РАН. М.: Наука, 2008. Вып. 582. С. 1-379]. 
Ponomarev V.S., 2011. Problems of Studying Energetically Active Geological Environment. Geotectonics 2, 66-75 (in Russian) [Пономарев В.С. Проблемы изучения энергетически активной геологической среды // Геотектоника. 2011. № 2. С. 66-75].

Pospelov G.L., 1972. Dispergites and Auto-Dispersion as an Important Problem in the Physics of Litho-Petro- and Tectogenesis. Geology and Geophysics 12, 53-73 (in Russian) [Поспелов Г.Л. Диспергиты и автодиспергация как важная проблема физики лито-петро- и тектогенеза // Геология и геофизика. 1972. № 12. С. 53-73].

Przhiyalgovsky E.S., Leonov M.G., Lavrushina E.V., 2014. Granitic Protrusions in the Structure of Intraplate Activation Zones, Southern Mongolia. Geotectonics 3, 50-77 (in Russian) [Пржиялговский Е.С., Леонов М.Г., Лаврушина Е.В. Гранитные протрузии в структуре зон внутриплитной активизации (Южная Монголия) // Геотектоника. 2014. № 3. C. 50-77]. https://doi.org/10.7868/S00 $16853 X 14030059$.

Psakhie S.G., Shil'ko E.V., Astafurov S.V., Grigoriev A.S., 2010. On the Possibility of Assessing the Proximity to a Critical Value of Shear Stresses at Active Interfaces in Block Media. In: Trigger Effects in Geosystems. Materials of the All-Russia Seminar-Meeting (22-24 June 2010, Moscow). GEOS, Moscow, p. 230-238 (in Russian) [Псахье С.Г., Шилько Е.В., Астафуров С.В., Григорьев А.С. О возможности оценки близости сдвиговых напряжений на активных границах раздела в блочных средах к критическому значению // Триггерные эффекты в геосистемах. Материалы всероссийского семинара-совещания (22-24 июня 2010, Москва). М.: ГЕОС, 2010. С. 230-238].

Psakhie S.G., Shil'ko E.V., Smolin A.Yu., Dimaki A.V., Dmitriev A.I., Konovalenko I.S., Astafurov S.V., Zavshek S., 2011. Development of the Approach to Modeling the Deformation and Fracture of Hierarchically Organized and Heterogeneous, Including Contrasting, Media. Physical Mesomechanics 14 (3), 27-54 (in Russian) [Псахье С.Г., Шилько Е.В., Смолин А.Ю., Димаки А.В., Дмитриев А.И., Коноваленко И.С., Астафуров С.В., Завшек С. Развитие подхода к моделированию деформирования и разрушения иерархически организованных и гетерогенных, в том числе контрастных, сред // Физическая мезомеханика. 2011. T. 14. № 3. C. 27-54].

Reiner M., 1947. Ten Lectures on Theoretical Rheology. Gostekhizdat, Moscow, 134 p. (in Russian) [Рейнер М. Десять лекций по теоретической реологии. М.: Гостехиздат, 1947. 134 с.].

Revuzhenko A.F., 2000. Mechanics of Elastoplastic Media and Nonstandard Analysis. Novosibirsk State University Publishing House, Novosibirsk, 428 p. (in Russian) [Ревуженко А.Ф. Механика упругопластических сред и нестандартный анализ. Новосибирск: Изд-во НГУ, 2000. 428 с.].

Revuzhenko A.F., 2003. Mechanics of Granular Medium. Publishing House of ZAO IPP Ofset, Novosibirsk, 274 p. (in Russian) [Ревуженко А.Ф. Механика сыпучей среды. Новосибирск: Изд-во ЗАО ИПП «Офсет», 2003. 274 с.].

Revuzhenko A.F., 2013. Tidal Waves and Directed Earth Mass Transfer. Nauka, Novosibirsk, 204 p. (in Russian)
[Ревуженко А.Ф. Приливные волны и направленный перенос масс Земли. Новосибирск: Наука, 2013. 204 с.].

Revuzhenko A.F., Bobryakov A.P., Kosykh V.P., 1997. On Flow of Granular Medium with Possible Unlimited Sliding on Localization Surfaces. Physical and Technical Problems of Mining 3, 37-42 (in Russian) [Ревуженко А.Ф., Бобряков А.П., Косых В.П. О течении сыпучей среды с возможным неограниченным скольжением по поверхностям локализации // Физико-технические проблемы разработки полезных ископаемых. 1997. № 3. С. 37-42].

Reynolds 0., 1885. On the Dilatancy of Media Composed of Rigid Particles in Contact. The London, Edinburgh, and Dublin Philosophical Magazine and Journal of Sciences 20 (127), 469-481. https://doi.org/10.1080/14786448508 627791.

Rodionov V.N., Sizov I.A., Tsvetkov V.M., 1986. Fundamentals of Geomechanics. Nedra, Moscow, 301 p. (in Russian) [Родионов В.Н., Сизов И.А., Цветков В.М. Основы геомеханики. М.: Недра, 1986. 301 с.].

Ruzhich V.V., 1997. Seismotectonic Destruction in the Crust of the Baikal Rift Zone. Publishing House of Siberian Branch of RAS, Novosibirsk, 144 p. (in Russian) [Ружич B.B. Сейсмотектоническая деструкция в земной коре Байкальской рифтовой зоны. Новосибирск: Изд-во СО РАН, 1997. 144 c.].

Sadovsky M.A., 1979. Natural Lumpiness of Rocks. Bulletin of the USSR Academy of Sciences 247 (4), 829-831 (in Russian) [Садовский М.А. Естественная кусковатость горной породы // Доклады АН СССР. 1979. Т. 247. № 4. C. 829-831].

Sadovsky M.A., 1989. On the Meaning and Sense of Discreteness in Geophysics. In: Discrete Properties of Geophysical Environment. Nauka, Moscow, p. 5-14 (in Russian) [Caдовский М.А. О значении и смысле дискретности в геофизике // Дискретные свойства геофизической среды. М.: Наука, 1989. С. 5-14].

Sadovsky M.A., Kocharyan G.G., Rodionov V.N., 1988. On the Mechanics of a Block Mountain Range. Bulletin of the USSR Academy of Sciences 302 (2), 306-308 (in Russian) [Садовский М.А., Кочарян Г.Г., Родионов В.Н. О механике блочного горного массива. Доклады АН СССР. 1988. T. 302. № 2. С. 306-308].

Sadovsky M.A., Mirzoev K.M., Negmatullaev S.Kh., Salomov I.G, 1981. Influence of Mechanical Micro-Vibrations on Plastic Deformation of Materials. Bulletin of the USSR Academy of Sciences. Physics of the Earth 5, 32-42 (in Russian) [Садовский М.А., Мирзоев К.М., Негматуллаев С.Х., Саломов И.Г. Влияние механических микроколебаний на характер пластических деформаций материалов // Известия АН СССР: Физика Земли. 1981. № 5. С. 32-42].

Seminsky K.Zh., 2003. Internal Structure of Continental Fault Zones. Tectonophysical Aspect. GEO, Novosibirsk, 244 p. (in Russian) [Семинский К.Ж. Внутренняя структура континентальных разломных зон. Тектонофизический аспект. Новосибирск: ГЕО, 2003. 244 с.].

Shemyakin E.I., Fisenko G.L., Kurlyanya M.V., Oparin V.N., Reva V.V., Glushikhin F.P., Rozenbaum M.A., Tropp E.A., Kuznetsov Yu.S., 1986. The Effect of Zonal Disintegration of Rocks 
around Underground Workings. Bulletin of the USSR Academy of Sciences. 289 (5), 1088-1094 (in Russian) [Шемякин Е.И., Фисенко Г.Л., Курляня М.В., Опарин В.Н., Рева В.В., Глушихин Ф.П., Розенбаум М.А., Тропп Э.А., Кузнецов Ю.С. Эффект зональной дезинтеграции горных пород вокруг подземных выработок // Доклады АН СССР. 1986. Т. 289. № 5. C. 1088-1094].

Sherman S.I., 2014. Seismic Process and Earthquake Forecasting: Tectonophysical Concept. GEO, Novosibirsk, 359 p. (in Russian) [Шерман С.И. Сейсмический процесс и прогноз землетрясений: тектонофизическая концепция. Новосибирск: ГЕО, 2014. 359 с.].

Sherman S.I., Gorbunova E.A., 2018. The Rheology of the Geological Medium of Interblock Seismically Active Faults in the Continental Lithosphere: A Key to Understanding the Generation of the Strongest Earthquakes in Central Asia. Geodynamics \& Tectonophysics 9 (3), 571-586 (in Russian) [Шерман С.И., Горбунова Е.А. Реология среды в межблоковых сейсмоактивных разломах континентальной литосферы - ключ к генерации сильнейших землетрясений в Центральной Азии // Геодинамика и тектонофизика. 2018. Т. 9. № 3. С. 571-586]. https://doi.org/10.5800/ GT-2018-9-3-0363.

Sherman S.I., Seminsky K.Zh., Bornyakov S.A., Buddo V.Yu., Lobatskaya R.M., Adamovich A.N., Truskov V.A., Babichev A.A., 1991. Faulting in the Lithosphere. Strike-Slip Zones. Vol. 1. Nauka, Novosibirsk, 261 p. (in Russian) [Шерман C.И., Ceминский К.Ж., Борняков С.А., Буддо В.Ю., Лобацкая Р.М., Адамович А.Н., Трусков В.А., Бабичев А.А. Разломообразование в литосфере. Зоны сдвига. Новосибирск: Наука, 1991. Т. 1. 261 с.].

Sherman S.I., Seminsky K.Zh., Bornyakov S.A., Buddo V.Yu., Lobatskaya R.M., Adamovich A.N., Truskov V.A., Babichev A.A., 1992. Faulting in the Lithosphere. Extension Zones. Vol. 1. Nauka, Novosibirsk, 227 p. (in Russian) [Шерман С.И., Cеминский К.Ж., Борняков С.А., Буддо В.Ю., Лобацкая Р.М., Адамович А.Н., Трусков В.А., Бабичев А.А. Разломообразование в литосфере. Зоны растяжения. Новосибирск: Наука, 1992. Т. 2.227 с.].

Sherman S.I., Seminsky K.Zh., Bornyakov S.A., Buddo V.Yu., Lobatskaya R.M., Adamovich A.N., Truskov V.A., Babichev A.A., 1994. Faulting in the Lithosphere. Compression Zones. Vol. 3. Nauka, Novosibirsk, 262 p. (in Russian) [Шерман С.И., Ceминский К.Ж., Борняков С.А., Буддо В.Ю., Лобацкая Р.М., Адамович А.Н., Трусков В.А., Бабичев А.А. Разломообразование в литосфере. Зоны сжатия. Новосибирск: Наука, 1994. Т. 3. 262 с.].

Shvab A.V., Martsenko M.S., 2011. Model of Motion of Highly Concentrated Granular Medium. Tomsk State University Bulletin. Mathematics and Mechanics 3 (15), 108-116 (in Russian) [Шваб А.В., Марценко М.С. Модель движения высококонцентрированной гранулированной среды // Вестник ТгУ. Математика и механика. 2011. Т. 3. № 15. C. 108-116].

Sibiryakov B.P., Podberezhny M.Yu., 2006. Instability of Structured Media and Some Scenarios for the Development of Catastrophes. Geology and Geophysics 47 (5), 684694 (in Russian) [Сибиряков Б.П., Подбережный М.Ю.
Неустойчивость структурированных сред и некоторые сценарии развития катастроф // Геология и геофизика. 2006. Т. 47. № 5. С. 684-694].

Sibiryakov E.B., Deev E.V., 2008. Using the Method of Boundary Integral Equations to Determine the Moduli of Granular Geological Bodies. Physical Mesomechanics 11 (1), 85-93 (in Russian) [Сибиряков Е.Б., Деев Е.В. Использование метода граничных интегральных уравнений для определения модулей гранулированных геологических тел //Физическая мезомеханика. 2008. Т. 11. № 1. С. 85-93].

Sitdikova L.M., Izotov V.G., 2003. Geodynamic Conditions for the Formation of Destructive Hydrocarbon Reservoirs at Deep Crust Horizons. Georesources 4 (12), 17-22 (in Russian) [Ситдикова Л.М., Изотов В.Г. Геодинамические условия формирования деструктивных резервуаров углеводородов глубоких горизонтов земной коры // Георесурсы. 2003. Т. 4. № 12. С. 17-22].

Sitharam T.G., Nimbkar M.S., 2000. Micromechanical Modelling of Granular Materials: Effect of Particle Size and Gradation. Geotechnical and Geological Engineering 18, 91117. https://doi.org/10.1023/A:1008982027109.

Sobolev G.A., Vettegren' V.I., Kireenkova S.M., Kulik V.B., Mamalimov R.I., Morozov Yu.A., Smul'skaya A.I., Scherbakov I.P., 2016. Nanocrystals in Rocks. GEOS, Moscow, 96 p. (in Russian) [Соболев Г.А., Веттегрень В.И., Киреенкова С.М., Кулик В.Б., Мамалимов Р.И., Морозов Ю.А., Смульская А.И., Щербаков И.П. Нанокристаллы в горных породах. М.: ГЕОС, 2016.96 с.].

Spivak A.A., Kishkina S.B., 2010. Precession of Structural Blocks of the Crust. In: Trigger Effects in Geosystems. Materials of the All-Russia Seminar-Meeting (22-24 June 2010, Moscow). GEOS, Moscow, p. 309-316 (in Russian) [Спивак А.А., Кишкина С.Б. Прецессия структурных блоков земной коры //Триггерные эффекты в геосистемах. Материалы Всероссийского семинара-совещания (2224 июня 2010, Москва). М.: ГЕОС, 2010. С. 309-316].

Stefanov Yu.P., 2002. Localization of Deformation and Destruction in Geomaterials. Numerical modeling. Physical Mesomechanics 5 (5), 107-118 (in Russian) [Стефанов Ю.П. Локализация деформации и разрушение в геоматериалах. Численное моделирование // Физическая мезомеханика. 2002. Т. 5. № 5. С.107-118].

Stefanov Yu.P., 2016. Some Nonlinear Effects of Rock Behavior. Physical Mesomechanics 19 (6), 54-61 (in Russian) [Стефанов Ю.П. Некоторые нелинейные эффекты поведения горных пород // Физическая мезомеханика. 2016. Т. 19. № 6. С. 54-61].

Stille H.W., 1964. Selected Papers. Mir, Moscow, 887 p. (in Russian) [Штилле Г.В. Избранные труды. М.: Мир, 1964. 887 c.].

Stroganov G.B., Kaybyshev O.A., Fatkullin O.Kh., Martynov V.N., 2002. Superplasticity and Wear Resistance in Mechanical Engineering. Alteks, Moscow, 322 p. (in Russian) [Строганов Г.Б., Кайбышев О.А., Фаткуллин O.Х., Мартынов В.Н. Сверхпластичность и износостойкость в машиностроении. М.: Альтекс, 2002. 322 с.].

Tejchman J., Wu W., 2007. Modeling of Textural Anisotropy in Granular Materials with Stochastic Micro-Polar 
Hypoplasticity. International Journal of Non-Linear Mechanics 42 (6), (882-894). https://doi.org/10.1016/j.ijnon linmec.2007.03.015.

Terpigorev A.M. (Ed.), 1958. Mining. Encyclopedic Guidebook. Vol. 1. Ugletekhizdat, Moscow, 458 p. (in Russian) [Горное дело. Энциклопедический справочник / Ред. А.М.Терпигорев. М.: Углетехиздат, 1958. Т. 1. 458 с.].

Thompson P.A., Grest G.S., 1991. Granular Flow: Friction and the Dilatancy Transition. Physical Review Letters 67 (13), 1751-1754. https://doi.org/10.1103/PhysRevLett.67.1751.

Trigger Effects in Geosystems. Abstracts of the 5th International Conference (4-7 June 2019, Moscow). GEOS, Moscow, 217 p. (in Russian) [Триггерные эффекты в геосистемах: Тезисы докладов V Международной конференции (4-7 июня 2019, Москва). М.: ГЕОС, 2019. 217 с.].

Voznesensky A.S., Krasilov M.N., Kutkin Ya.O., Tavostin M.N., Tyutcheva A.Yu., Nasibullin R.R., Luchnikova A.O., 2019. Trigger effect of periodic force on rocks. In: Trigger Effects in Geosystems. Abstracts of the 5th International Conference (4-7 June 2019, Moscow). GEOS, Moscow, p. 43-44 (in Russian) [Вознесенский А.С., Красилов М.Н., Куткин Я.О., Тавостин М.Н., Тютчева А.Ю., Насибуллин Р.Р., Лучникова А.О. Триггерный эффект периодического силового воздействия на горные породы //Триггерные эффекты в геосистемах: Тезисы докладов V Международной конференции (4-7 июня 2019, Москва). М: ГЕОС, 2019. С. 43-44].
Yaeger H.M., Nagel S.R., 1992. La Physique de l'Etat Granulaire. La Recherche 249, 1380-1387.

Yaeger H.M., Nagel S.R., 1996. The Physics of Granular Materials. Physics Today 49 (4), 32-38. https: //doi.org/10. 1063/1.881494.

Zapivalov N.P., 2014. Innovative Technologies in Exploration and Development of Oil and Gas Fields Based on the New Geological Paradigm. Georesursy 1 (56), 23-28 (in Russian) [Запивалов Н.П. Инновационные технологии в разведке и разработке нефтегазовых месторождений на основе новой геологической парадигмы // Георесурсы. 2014. № 1 (56). C. 23-28].

Zykov D.S., 1997. Paragenesis of Neotectonically Activated Structures of the Crystalline Basement of Karelia. In: Structural Paragens and Their Ensembles. Materials of the Meeting. GEOS, Moscow, p. 55-57 (in Russian) [Зыков Д.С. Парагенезы неотектонически активизированных структур кристаллического фундамента Карелии // Структурные парагенезы и их ансамбли: Материалы совещания. М.: ГЕОС, 1997. С. 55-57].

Zykov D.S., 1999. Manifestations of the Latest Tectonic Volumetric Mobility of Rock Masses in Karelia. Bulletin of the Russian Academy of Sciences 264 (2), 216-218 (in Russian) [Зыков Д.С. Проявления новейшей тектонической объемной подвижности горных масс в Карелии // Доклады РАН. 1999. Т. 264. № 2. С. 216-218]. 